\title{
Towards a marine strategy for the deep Mediterranean Sea: Analysis of current ecological status
}

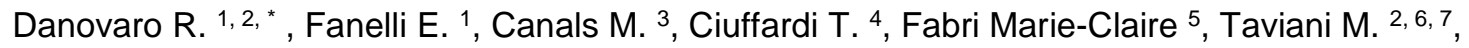
Argyrou M. ${ }^{8}$, Azzurro E. ${ }^{2,}{ }^{9}$, Bianchelli S. ${ }^{1}$, Cantafaro A. ${ }^{10}$, Carugati L. ${ }^{1}$, Corinaldesi C. ${ }^{11}$, De Haan W.P. ${ }^{3}$, Dell'anno A. ${ }^{1}$, Evans J. ${ }^{10}$, Foglini F. 6 , Galil B. ${ }^{12}$, Gianni M. ${ }^{13}$, Goren M. ${ }^{12}$, Greco S. ${ }^{2}$, Grimalt J. ${ }^{14}$, Güell-Bujons Q. ${ }^{3}$, Jadaud Angelique ${ }^{15}$, Knittweis L. ${ }^{10}$, Lopez J.L. ${ }^{14}$, Sanchez-Vidal A. ${ }^{3}$,

Schembri P.J. ${ }^{10}$, Snelgrove P. ${ }^{16}$, Vaz Sandrine ${ }^{15}$, Angeletti L. ${ }^{17}$, Barsanti M. ${ }^{18}$, Borg J.A. ${ }^{19}$, Bosso M. ${ }^{18}$, Brind'Amour Anik ${ }^{20}$, Castellan G. ${ }^{17}$, Conte F. ${ }^{18}$, Delbono I. ${ }^{18}$, Galgani Francois ${ }^{20}$, Morgana G. ${ }^{18}$, Prato S. ${ }^{18}$, Schirone A. ${ }^{18}$, Soldevila E. ${ }^{21}$

1 Department of Life and Environmental Sciences, Polytechnic University of Marche, 60131, Ancona, Italy

2 Stazione Zoologica Anton Dohrn Naples, 80122, Naples, Italy

${ }^{3}$ CRG Marine Geosciences, Department of Earth and Ocean Dynamics, Faculty of Earth Sciences, University of Barcelona, 08028, Barcelona, Spain

${ }^{4}$ Italian National Agency for New Technologies, Energy and Sustainable Economic Development (ENEA), Department for Sustainability, S. Teresa Marine Environment Research Centre, 19100, La Spezia, Italy

5 Institut Français de Recherche pour l'exploitation de la Mer (Ifremer), Département Océanographie et Dynamique des Ecosystèmes, 83500, La Seyne sur Mer, France

6 Institute of Marine Sciences (ISMAR), CNR, 40129, Bologna, Italy

7 Biology Department, Woods Hole Oceanographic Institution, MA, 02543, USA

8 Department of Fisheries and Marine Research (DFMR), 1416, Nicosia, Cyprus

9 Institute for Environmental Protection and Research (ISPRA) STS Livorno, 57122, Italy

10 Department of Biology, University of Malta, Msida, MSD2080, Malta

11 Department of Sciences and Engineering of the Materials, Environment and Urban Planning, Polytechnic University of Marche, Italy

12 The Steinhardt Museum of Natural History, Israel National Center for Biodiversity Studies, Tel Aviv University, Tel Aviv, 69978, Israel

${ }^{13}$ Deep Sea Conservation Coalition, Postbus, 59681, Amsterdam, Netherlands

14 Department of Environmental Chemistry, Institute of Environmental Assessment and Water Research (CSIC), 08034, Barcelona, Spain

15 UMR Marbec, Ifremer, IRD, Université de Montpellier, CNRS, 34203, Sète Cedex, France

${ }^{16}$ Departments of Ocean Sciences and Biology, Memorial University of Newfoundland, St. John's, NL

A1C 5 S7 ,Canada

17 Institute of Marine Sciences (ISMAR), CNR, 40129, Bologna, Italy

18 Italian National Agency for New Technologies, Energy and Sustainable Economic Development

(ENEA), Department for Sustainability, S. Teresa Marine Environment Research Centre, 19100, La Spezia, Italy

19 Department of Biology, University of Malta, Msida, MSD2080, Malta

20 Institut Français de Recherche pour l'exploitation de la Mer (Ifremer), Département Océanographie et Dynamique des Ecosystèmes, 83500, La Seyne sur Mer, France

${ }^{21}$ CRG Marine Geosciences, Department of Earth and Ocean Dynamics, Faculty of Earth Sciences,

University of Barcelona, 08028, Barcelona, Spain 
* Corresponding author : R. Danovaro, email address : $\underline{\text { r.danovaro@univpm.it }}$

\begin{abstract}
:
The Marine Strategy Framework Directive (MSFD), introduced in June 2008, was adopted to achieve a Good Environmental Status (GES) in the EU's marine waters and to protect resources of socio-economic interest. The MSFD exerts to the marine area over which a Member State exercises jurisdictional rights in accordance with the United Nations Convention on the Law of the Sea (UNCLOS), including the deepsea waters, seafloor and sub-seafloor of the Exclusive Economic Zones (EEZ). However, currently the MSFD focuses on coastal habitats and the shallow-water seafloor to the detriment of the deeper habitats. Despite the huge dimension of the deep sea (below $200 \mathrm{~m}$ of depth) covering more than $65 \%$ of the Earth's surface and including $>95 \%$ of the global biosphere, the relevance of the dark portion of the seas and oceans is still almost completely neglected. Given the important bi-directional links between shallow and deep ecosystems, there is a clear need for extending the implementation of the MSFD into the deep sea, to define a sound ecosystem-based approach for the management and protection of deep-sea ecosystems and attain GES. We assembled data on drivers, anthropogenic pressures and impacts concerning the MSFD descriptors pertaining to the Mediterranean deep sea. We list deep-sea monitoring activities and the main sources providing benchmark conditions, and discuss knowledge and geographic coverage gaps. MSFD descriptors apply to the deep sea as to coastal waters, and ought to be monitored contemporaneously. We provide recommendations for guidelines for future deep-sea monitoring in the Mediterranean Sea.
\end{abstract}

\title{
Highlights
}

- MSFD fails to cover the huge dimension of deep-sea environments and important bi-directional link with shallow ones. Extending MSFD to the deep sea and defining an ecosystem-based approach for its management and protection is urgently needed. Data on drivers, anthropogenic pressures and impacts regarding the MSFD descriptors for deep-sea Mediterranean were reviewed. Deep-sea monitoring activities were discussed and knowledge and geographic coverage gaps evidenced. Recommendations for guidelines for future deep-sea monitoring were provided.

Keywords : Marine strategy framework directive, Deep-sea ecosystems, Mediterranean basin 
6 List of acronyms and abbreviations

7 ABNJ: Areas Beyond National Jurisdiction

8 ACCOBAMS: Agreement on the Conservation of Cetaceans in the Black Sea Mediterranean Sea and

9 Contiguous Atlantic Area

10 AUV: Autonomous Underwater Vehicle

11 CBD: Convention on Biological Diversity

12 CFP: Common Fisheries Policy

13 CWC: Cold-Water Corals

DCF: Data Collection Framework

SF: Deep-Sea Fisheries

16 DSWC: Dense Shelf Water Cascading

17 EEZ: Exclusive Economic Zone

18 EFH: Essential Fish Habitats

19 EIA: Environmental Impact Assessment

20 EMT: Eastern Mediterranean Transient

21 EwE: Ecopath with Ecosim

22 FAO: Food and Agricultural Organization

23 FRA: Fishery Restricted Areas

24 GFCM: General Fisheries Commission for the Mediterranean

25 GSA: Geographical Sub Area

26 ICCAT: International Commission for the Conservation of Atlantic Tunas

27 LIW: Levantine Intermediate Water

28 MBES: Multibeam Echosounder

29 MEDIAS: Mediterranean International Acoustic Survey

30 MEDITS: Mediterranean International Trawl Survey

31 MS: Member States

32 MSFD: Marine Strategy Framework Directive

33 MSY: Maximum Sustainable Yield

34 NIS: Non-Indigenous Species

35 OMZ: Oxygen Minimum Zones

36 PAH: Polycyclic Aromatic Hydrocarbons

37 POM: Particulate Organic Matter

38 POP: Persistent Organic Pollutants

39 ROV: Remotely Operated Vehicle

40 SAC: Scientific Advisory Committee

41 SCA: Stomach Content Analysis

42 SSB: Spawning Stock Biomass

43 SIA: Stable Isotope Analysis

44 SSS: Side-Scan Sonar

45 STECF: Scientific, Technical and Economic Committee for Fisheries

46 VME: Vulnerable Marine Ecosystem

47 UNCLOS: United Nations Convention on the Law of the Sea

48 UNGA: United Nations General Assembly 49 


\section{Introduction}

\subsection{The Mediterranean Sea}

The Mediterranean is a semi-enclosed basin between the European and African coasts with the narrow and shallow Strait of Gibraltar connecting its waters and life to the Atlantic Ocean. The Suez Canal creates a man-made connection to the Red Sea, recently doubled, which allows the penetration of tropical Indo-pacific species (Longhurst, 2017). Concomitantly, the Mediterranean Basin is experiencing major climatic-related changes that are strongly influencing its oceanography in terms of water mass characteristics (e.g., temperature, salinity, dissolved oxygen), currents, nutrients and relative sea levels. The interplay of these factors has, since historical times, strongly influenced the diversity and colonization of the Mediterranean Sea (Taviani, 2002; Danovaro et al., 2010).

Unique hydrology characterizes the present-day Mediterranean, including microtidal regime, oligotrophy, high salinity (37.5-39.5 psu), homoeothermic temperatures from $300-500 \mathrm{~m}$ to the bottom, with values at the seafloor ranging from ca $13-13.5^{\circ} \mathrm{C}$ in the western basin to $13.5-15.5^{\circ} \mathrm{C}$ in the eastern basin, and the almost complete lack of thermal boundaries (Emig and Geistdoerfer, 2005). These features uniquely make the Mediterranean one of the "warmest" deep-sea basins of the world. Strong energy gradients also characterize the Mediterranean, with primary production and food supply to the deep decreasing from the western to the eastern region of the basin and from shallower to deeper waters (Danovaro et al. 1999).

These historical, topographic and environmental characteristics complicate deep-sea biodiversity patterns of the Mediterranean Sea but raise intriguing questions. Numerous studies document that the Mediterranean Sea, although modest in size $(0.82 \%$ and $0.32 \%$ of the global ocean surface and volume, respectively; Bianchi and Morri, 2000), is a biodiversity hot spot with overall ca 17000 species, which represent $7.5 \%$ of the species richness of the oceans (Danovaro and Pusceddu, 2007; Coll et al., 2010; Lejeusne et al., 2010). However, although data on the species richness of its deeper habitats are incomplete (two thirds of the deep species - excluding prokaryotes - have not been censused yet; Ramirez-Llodra et al., 2009; Coll et al., 2010, Danovaro et al., 2010), it appears that the biodiversity of the deep Mediterranean basin is lower than that of other oceans (Danovaro et al. 2010).

The biodiversity of the deep Mediterranean Sea depends largely from the heterogeneity of habitats, which include submarine canyons and seamounts, continental rise deposits, mud volcanoes and extreme environments such as hydrothermal vents, cold seeps and deep- 

hypersaline anoxic basins (Olu-Le Roy et al., 2004; Danovaro et al., 2010; Taviani, 2011, 2014; Fernandez-Arcaya et al., 2017). Even seemingly "featureless" soft bottom habitats host unique and 105 vulnerable species and habitats (e.g. sponge fields, gorgonian and pennatulacean meadows) 106 (Danovaro et al., 2010).

\subsection{Implementing the Marine Strategy Framework Directive in the deep Mediterranean Sea}

133 Integrated Maritime Policy tool to achieve Good Environmental Status (GES) of marine waters, 134 with an initial target for 2020. The MSFD applies to the area of marine waters over which a 
Member State exercises jurisdictional rights in accordance with the UNCLOS (see Figure 1, for the definition of territorial waters and EEZs in the Mediterranean). These include also deep-sea

137 waters, seabed and sub-seafloor. At present, MSFD implementation focuses mostly on coastal 138 habitats or those impacted by commercial fisheries (Raicevich et al., 2017). However, over long139 time scales, global nutrient and carbon cycles depend on a functioning deep sea (e.g. Snelgrove et al., 2018). Moreover, the life-cycle stages of some coastal species use offshore environments, thus 141 achieving GES for marine ecosystems associated with continental shelves, must link to the 142 achievement of GES for deep Mediterranean environments and Areas Beyond National Jurisdiction 143 (ABNJ or "High Seas"). Otherwise, the MSFD will largely disregard the precautionary principle and undermine an ecosystem-based approach to marine management.

An effective governance and management of the Mediterranean Sea requires consideration of the complexity of these environmental issues, and meaningful international cooperation (de Vivero and Rodriguez Mateos, 2015). Given the transboundary nature of most of the deep waters, their inclusion in MSFD complicates the requirement for each Member State to apply the Directive to areas within its national jurisdiction. This emphasizes the need for Member States (MS) to cooperate in order to ensure coordinated and harmonized development of marine strategies at the scale of region/sub-region in the Mediterranean Basin, where EU MS and developing countries co-exist.

MSFD implementation currently suffers from a lack of standardized and consistent methodology for deep waters. To address this gap, we identify approaches, variables, and methodologies to enable MSFD implementation in the deep Mediterranean Sea. This synthesis summarises available information on MSFD descriptors for the deep Mediterranean Sea, with respect to the criteria listed in the European Commission Decision (COMM/DEC/2017/848), and anthropogenic pressures, uses and human activities affecting the marine environment (Table 2 of Annex III of COMM/DEC/2017/848).

\section{State of the knowledge of MSFD descriptors in the deep Mediterranean}

\subsection{Descriptor 1: Biological diversity}

Descriptor 1 (D1) states that "The quality and occurrence of habitats and the distribution and abundance of species are in line with prevailing physiographic, geographic and climatic conditions" (MSFD, 2008/56/EC, Annex I, summarised in Table 1). The species groups specified in Part II of the Annex to COMM/DEC/2017/848, these include birds, mammals, reptiles, fish and 
167

168

cephalopods, some of which are present, diverse and abundant in the deep sea, such as fishes and cephalopods, in addition to deep diving and feeding cetaceans. Deep-sea organisms play an important role in marine food webs, either as predators or as important prey of a large set of high trophic level predators, including other fishes and cephalopods and marine mammals (Fanelli et al., 2012, 2013; Quetglas et al., 2013).

Data on these components from the deep Mediterranean Sea are largely included in the MEDITS database, which also represent the only extensive time series available for the deep Mediterranean (Bertrand et al., 2002), although with the limitation that it is a destructive sampling method with discrete sampling time, which exclude the possibility to detect any displacements of demersal species (Aguzzi et al., 2009; 2013). MEDITS is funded as part of the EU Data Collection multi-annual sampling program (DC-MAP), which limits the sampling frequency to yearly surveys confined to the northern part of the Mediterranean Basin. MEDITS mostly targets demersal fish (including deep-sea sharks), but includes also commercial invertebrates and other macro and mega-invertebrates (as by-catch species). MEDITS provides detailed information on their abundance and biomass, including the population structure of several species (including length frequency distributions by sex and maturity stages for different target species), which allow us to obtain information on the size spectra, maturity ogives, sex ratios and mortality rates. This information contributes to both the census of shallow and deep marine biodiversity and stock assessments carried out by the GFCM and the STECF of the European Commission (see Vasilakopoulos et al., 2014; Cardinale et al., 2017) [see Descriptor 3 below]. In the case of mesoand bathypelagic species (MEDIAS Handbook, 2015; i.e. Galil, 2004; Papiol et al., 2013; Fanelli et al., 2013, 2015; Valls et al., 2014), species of non-commercial interest, hard bottom habitats between 200 and $800 \mathrm{~m}$ depth, and in general all habitats below $800 \mathrm{~m}$ depth, only scattered information without temporal datasets exist.

Another important gap concerns the smaller size biota, such as meiofauna, which are a key component in the deep-sea ecosystems and are driven by water depth, regional setting and geomorphological characteristics of the deep Mediterranean habitats (Bianchelli and Danovaro, 2019). Meiofauna are highly diversified (possibly hyper-diverse), and play a fundamental ecological role in the biogeochemical cycles and in food webs and are sensitive to environmental and anthropogenic pressures (Pusceddu et al., 2014). Since this component, which increases its ecological relevance, in terms of abundance and functional role, with increasing water depths (Danovaro et al., 2015), has been recently suggested for inclusion in the D1 for the 
199 implementation of the MSFD (Semprucci et al., 2014; Bianchelli et al., 2016a; 2018). It is even 200 more evident that it should be taken into consideration in the implementation of the MSFD in the 201 deep sea.

The MSFD deep-sea habitats included in the COMM/DEC/2017/848 are: a) upper bathyal 203 rocks and biogenic reefs, b) upper bathyal sediments, c) lower bathyal rock and biogenic reef, d) 204 lower bathyal sediments, and e) abyssal seafloor. These include other benthic habitats such as: 205 canyons (which may include rocky and sedimentary substrates), rocky bottoms with coral banks 206 (including Cold-water corals) or large bivalves, different types of sedimentary bottoms in bathyal 207 or abyssal plains (muds, sands or coarser sediment), chemosynthetic ecosystems (hydrothermal 208 vents and mud volcanoes), and seamounts.

Previous studies on the deep Mediterranean Sea reported a west-east decreasing gradient 210 of food availability (Danovaro et al., 1999; Danovaro et al., 2008), which explains the presence of a 211 significant decreasing gradient in the abundance and biomass of most deep-sea benthic 212 components along that gradient, from meiofauna to megafauna (Sardá et al., 2004; Bianchelli and 213 Danovaro, 2019; Fanelli et al., 2018). The CWCs apparently follow the same gradient (Taviani et al., 214 2017; Chimienti et al., 2019), and the presence of Levantine Intermediate Water (LIW) likely 215 strongly influences their distribution (Freiwald et al., 2009; Taviani et al., 2016, 2017).

216 Trawl surveys provide most of the available information on deep-sea habitats and their 217 characteristics (see Table 1, Annex III, MSFD), but only for soft bottom habitats including those 218 dominated by Isidella elongata and Funiculina quandrangularis (Lauria et al., 2017; Vasilis et al., 219 2019). Oceanographic cruises using ROVs offer the possibility to conduct non-destructive image 220 and sample collections able to contribute significantly to the study of deep-sea habitats. Most ROV 221 surveys to date have focused on CWC habitats and coral gardens, and provide important 222 information on the composition, abundance, and biomass of the communities within these 223 habitats (Taviani et al., 2005, 2011, 2015, 2019; Schembri et al., 2007; Fabri et al., 2014, 2017; Bo 224 et al., 2015; Evans et al., 2016; Fanelli et al., 2017; Chimienti et al., 2019; Moccia et al., 2019). 225 Most available information focuses on deep-sea canyons (Migeon et al., 2012), seamounts (Wurtz 226 and Rovere, 2015) and mud volcanoes (Mascle et al., 2014), with major data gaps for deep-sea 227 pelagic habitats, notwithstanding there is an increasing information on deep-water zooplankton 228 and micronekton (Koppelmann et al., 2009; Fanelli et al. 2011, 2014; Cartes et al., 2013; Denda 229 and Christiansen, 2014; Danovaro et al., 2017; Conese et al., 2019). Descriptor 1 is directly linked 230 to D2, D3, D4 and D6 (habitats), and monitoring efforts in the deep sea can therefore gather 
231 contextual information on all these descriptors. The ecosystem criteria listed in 232 COMM/DEC/2017/848, which link Descriptors 1 and 4, consider trophic guilds. These are highly 233 relevant to the deep sea and can therefore be immediately described, as the already available 234 data would provide the required background information.

\subsection{Descriptor 2: Non-indigenous species introduced by human activities}

236 The number of recorded Non-Indigenous Species (NIS) in the Mediterranean Sea greatly 237 exceeds that in other European seas (Galil et al., 2014; Zenetos, 2019). Their establishment alters 238 biotic assemblages and ecosystem functions (Galil, 2007; Katsanevakis et al., 2007; Fanelli et al., 239 2015; Galil et al., 2016, 2017; Goren et al., 2016; Azzurro et al., 2019). The Suez Canal is an 240 important pathway for Red Sea species, which indeed represent $2 / 3$ of the NIS in the 241 Mediterranean Sea (Galil et al., 2017). In the past, it was assumed that NIS could establish only in 242 shallow waters, however, the deep sea is not immune to species invasions. NIS have been rarely 243 documented in the deep sea, a notable exception is the red king crab Paralithodes camtschaticus 244 in the Barents Sea (Jørgensen and Nilssen, 2011). Yet, a growing number of Erythraean species 245 were reported from the deeper part of the continental shelf, beyond the shelf break and in the 246 upper slope (Özcan et al., 2008; Corsini-Foka et al., 2010; Innocenti et al., 2017; Özgür Özbek et al., 247 2017). For example, the lethally poisonous silver-cheeked toadfish, Lagocephalus sceleratus, has 248 been collected from 350-400 m depth off Spain (Izguerdo-Munoz and Izguerdo-Gomez, 2014). The 249 invasive lionfish, Pterois miles, that was initially present only in the upper shelf has been recently 250 recorded at depths down to 110-150 m (Yağlioğlu and Ayas, 2016; Jimenez et al., 2019). In the 251 southern Levantine Sea, three carnivorous species of Erythraean origin have been observed at 200 252 m depth: the crocodile toothfish Champsodon nudivittis, the burrowing goby Trypauchen vagina 253 and the red-eye round herring Etrumeus golanii (Galil et al. 2018). The presence of deeper 254 dwelling populations suggests that thermal niche assessments based only on a species' native 255 range may underestimate their ability to tolerate lower temperatures (Parravicini et al. 2015). 256 Wider thermal tolerance of some Erythraean species may facilitate their bathymetric and 257 geographic expansion to depths where unique, diverse, and fragile mesophotic 'animal forests' 258 occur. The lately observed "descent" of NIS from the upper to lower continental shelf may be an 259 indication of temperature-dependent range expansion at increasing water depths, and appears to 260 be accelerating. Therefore, even if abundances of NIS at levels of true invasions have not been 261 reported yet in the deep Mediterranean, these vulnerable environments should be monitored also 262 for D2, as they could be future targets of NIS invasions. 
264 2.3 Descriptor 3: Populations of commercially exploited fish and shellfish

Descriptor 3 determines that Member States should maintain commercially exploited stocks 266 of fish and shellfish in a healthy state. This descriptor implies sustainable exploitation that does i.e. Descriptor 4 addresses the question of trophic relationships and marine food webs. The MSFD 277 builds on existing EU legislation such as the Common Fishery Policy (CFP), and the criteria describing stock status follow internationally acknowledged best practices. The SAC of the GFCM, 280 or swordfishes, which account for more than $10 \%$ of the value of the total catches in the 281 Mediterranean) collectively monitor exploitation of fisheries resources in the Mediterranean marine sub-regions. The FAO and GFCM oversee collection of fisheries monitoring data in the 283 Mediterranean Sea within GSAs (Geographical Sub Areas management divisions, according to 284 resolution GFCM/33/2009/2, www.gfcm.org, for the correspondence between GSA numbers and 285 their names Fig. 2), often assessing stocks over one or several GSAs. However, the MSFD sub286 regions do not match with the GSAs. Furthermore, when we focus our attention on depths $>200$ $287 \mathrm{~m}$, the distinction between shallow and deep-water species is often irrelevant because 288 distribution, exploitation and assessment of many stocks often cover wide depth ranges.

Descriptor 3 stipulates the need for fishery-induced mortality, yielding (but not exceeding) 290 MSY (D3C1), and that populations of all commercially exploited species should remain within safe 291 biological limits (D3C2), with a population age and size distribution (D3C3) indicative of a healthy 292 stock. Fulfilling D3 criteria for deep-sea stocks requires: (1) sustainable exploitation consistent 293 with high long-term yields, (2) maintaining full reproductive capacity in order to maintain stock 294 biomass, and (3) maintaining or increasing the proportion of older and larger fish/shellfish, an 
295 indicator of a healthy stock. Achieving GES also for a deep-sea stock requires fulfilling all three of 296 these attributes and, for the reasons highlighted above, D3 indicators require trans-national 297 cooperation at the level of each MFSD sub-region.

In the Mediterranean Sea, the enforcement of the CFP and, more recently, of the MSFD, 299 continues to fall far short of achieving its objectives for exploited living marine resources (e.g., 300 Colloca et al., 2013; Vasilakopoulos et al., 2014). Notwithstanding the enforcement of the EU-Data 301 Collection Regulation (EU, 2000) in the early 2000s by all EU Member States, and the rapid 302 increase in the number of assessed stocks by the GFCM and the STECF, industries continue to 303 exploit Mediterranean Sea marine resources above MSY levels, with few signs of population 304 recovery (Vasilakopoulos et al., 2014; Cardinale et al., 2017; Colloca et al., 2017).

Management practices of DSF and VMEs in the Mediterranean were reviewed in 2016 and 3062017 (FAO, 2016 and GFCM, 2017). UNGA Resolutions 51/2006 and the FAO International 307 also IDEM 2018a). GFCM banned the use of towed dredges and trawl nets at depths beyond 1,000 $318 \mathrm{~m}$ in 2005 (Recommendation GFCM/29/2005/1), protecting over ca. 1,700,000 $\mathrm{km}^{2}$ of 319 Mediterranean Sea seafloor habitats (about 59\% of the GFCM area of application) (FAO, 2018).

321 Essential Fish Habitats (EFHs) or/and VMEs from excessive fishing mortality or the significant 322 adverse impact of fishing activities through bottom-contact fishing gears, respectively. The FRAs encompass a total marine area of ca. $22,500 \mathrm{~km}^{2}$ (FAO, 2018). Four of the FRAs were declared 324 within a multiannual management plan for deep-sea fisheries, in order to protect EFHs for 325 spawners of several species that are heavily exploited, to maintain habitat of the continental slope 326 (canyons and submarine canyons), and to preserve all the species of the area (commercially 

exploited or not), i.e., one in the Gulf of Lion in France (Le Corre and Farrugio, 2011), one in the 328 Jabuka-Pomo Pit (Elahi et al., 2018) and two FRAs south of Sicily. The existence of management 329 plans, however, does not necessarily imply regular completion of accurate stock evaluation. 330 Moreover, the existence of the FRA does not necessarily imply banning bottom trawling and may 331 simply represent an effort management tool (to prevent further effort increase as seen in freezing 332 fishing effort in the Gulf of Lion FRA).

Member States shall establish a list of commercially exploited species to which the criteria 334 apply in each assessment area through regional or sub-regional cooperation, and update that list 335 for each six-year evaluation period, taking into account Council Regulations (EU) 1251/2016, 336 1380/2013, 1343/2011, and 1967/2006, in accordance with article 43 (3) of the Treaty on the 337 Functioning of the European Union, article 9 of Regulation (EU) No 1380/2013 and article 19 of 338 Regulation (EC) No 1967/2006.

339 The MSFD criteria available for coastal environments cannot often be directly utilised for 340 deep-sea species. This is because stock assessments are limited and not sufficiently monitored, 341 hampering the assessment of stock exploitation at MSY (Criterion D3C1). The available 342 information decreases eastwards and southwards. In addition, a gap of knowledge is also present 343 in terms of time-series coverage of Spawning Stock Biomass (SSB) (Criterion D3C2) trend data 344 hampering the possibility to define appropriate reference points.

345 The third criterion, i.e. "Healthy age and size structure" (criterion D3C3), assumes that a 346 stock with sufficient large, and therefore old, fish corresponds to a healthy stock, thus reflecting 347 good status. The larger and older fish stocks indicate healthier conditions, but this criterion has 348 not been developed because GES lacks accepted thresholds (European Environment Agency, 349 2018).

350 This gap suggests a need to identify and test suitable indicators, metrics, and thresholds for 351 populations and age size distributions for each deep-sea stock (ICES, 2016, 2017). In conclusion, 352 our analysis points out that there is a potential to inform D3 criteria, but more data need to be 353 collected in the future to propose sound stocks analyses and reference conditions, likely though 354 the extension of the EU Data Collection Multiannual Programme (DC-MAP, EU Regulation 355 2016/1701) to include more deep-sea species. 356

357 2.4 Descriptor 4: Marine food webs 
Descriptor 4 addresses the functional aspects of marine food webs, especially the rates of 359 energy transfer within the system and levels of productivity in key components. In the context of 360 the MSFD, this descriptor reaches GES when "All elements of the marine food webs, to the extent 361 that they are known, occur at normal abundance and diversity and population levels capable of 362 ensuring the long-term abundance of the species and the retention of their full reproductive 363 capacity" (MSFD, 2008/56/EC, Annex I).

364 Deep-sea food webs critically depend on input of organic carbon from the photic zone 365 (Thomsen et al., 2017). The microbial loop and viral infections can play an important role in the 366 functioning of deep-sea food webs both in the water column and in sediments, and in the control 367 of the biogeochemical cycles (Danovaro et al., 2008). At the same time, deep-sea meiofauna 368 represents a potential basic linkage in energy transfer from the benthic detritus and microbes to 369 the macro- megafauna and demersal fishes (Van Oevelen et al., 2011; Gambi et al., 2014)

D4 is one of the most controversial MSFD Descriptors in terms of protocols, criteria, and 371 thresholds (ICES, Report 2015). D4 is generally investigated along with Descriptors D1 and D6 or 372 D3. Studies of food web properties typically utilize two different approaches: a) Stomach Contents' 373 Analyses (SCA) and b) Stable Isotope Analyses (SIA), and fatty acid trophic markers. Modelling 374 techniques, in contrast, can provide insights regarding the potential structure of food webs

375 (Rombouts et al., 2013). SIA identified three trophic levels among deep-sea supra-benthos (Fanelli 376 et al., 2009) and four levels within macrozoobenthos (Iken et al., 2001; Fanelli et al., 2011a) and 377 macrozooplankton/micronekton (Fanelli et al., 2011b). Fishes, decapods, and cephalopods 378 dominate higher trophic levels in deep-sea demersal communities. Despite the availability of a 379 large dataset for the deep Mediterranean Sea (MEDITS, 2002), this dataset includes few 380 commercial species from bathyal depths: the European hake Merluccius merluccius and the 381 greater forkbeard Phycis blennoides, some sharks (mostly Etmopterus spinax and Galeus 382 melastomus), decapods (the red shrimps Aristaeus antennatus and Aristaeomorpha foliacea, the 383 rose shrimp Parapenaeus longirostris and the Norway lobster Nephrops norvegicus). We lack 384 sufficient data on other dominant deep-sea species, such as macrourids, or key predators such as deep-sea sharks (e.g., Centroscymus coelolepis; Stefanescu et al., 1994; Massutí et al., 2004; Anastosopoulou et al., 2016).

388 decapods, cephalopods and echinoderms), whereas few studies are available on other biotic 389 compartments such as meiofauna or mesozooplankton (Danovaro et al., 2010). The northwestern 

Mediterranean portion is better studied (Fanelli et al., 2009, 2011a, b, 2013, 2015, 2016; Papiol et al., 2013; Cresson et al., 2014), whereas the Ionian and Aegean seas have been much less 392 investigated (Carlier et al., 2009; Koppelmann et al., 2009; Tecchio et al., 2013; Cartes et al., 2014; 393 Naumann et al., 2015). On the other hand, these types of studies rarely consider some key 394 species/taxa, such as mesopelagic fishes or megazooplankton (Fanelli et al., 2014; Valls et al., 395 2014).

COMM/DEC/848/2017 sets criteria and methodological standards for monitoring and 397 assessment of GES within the theme "Ecosystems". For example, selection criteria require that at 398 least one of the three trophic guilds monitored should focus on primary producers. This criterion is 399 the major drawback for this descriptor given that, aside from the few, very localized ecosystems 400 that depend on chemosynthesis (hydrothermal vents, cold seeps, or wood and whale falls; Luna et 401 al., 2012; Molari et al., 2013), the vast majority of the deep sea lacks primary production. The data gap between experimental and functional data adds further complication.

Stable isotope analysis may comply with the primary criterion D4C1 (diversity of trophic guilds) and the secondary criterion D4C3 (distribution of individuals across the trophic guild). Moreover, in combination with abundance, biomass, and other biological data available from MEDITS data, it may offer inputs into ecosystem models that could generate useful outputs, such as identification of unrecognized keystone species, a gap not presently considered. Italy addresses 408 D4 under its fishery monitoring program (i.e. D3) and specifically with three subprograms aimed at: i) defining, testing, and applying ecosystem indicators through models (essentially EwE, 410 http://www.ecopath.org); ii) identifying functional groups through the application of stable 411 isotope analysis of monitored species within the DCF; and iii) integrating analysis of commercial 412 species with those for benthos, zooplankton and Particulate Organic Matter (POM) samples every 413 three years. Spain and France recently introduced SIA and SCA of species collected during MEDITS 414 or MEDIAS surveys for use in D4.

In conclusion, the analysis of D4 can be realistically initiated for the deep Mediterranean, 416 using the available technologies, protocols and monitoring programs and adapting the criteria, by 417 neglecting the relevance of primary production, which could be replaced by the analysis of the 418 inputs of primary organic matter and/or by starting from primary consumers and/or including the 419 chemosynthetic primary production.

420

\subsection{Descriptor 5: Human-induced eutrophication}


Eutrophication refers to "a process driven by enrichment of water by nutrients, especially

423 compounds of nitrogen and/or phosphorus, leading to increased primary production and biomass

424 of algae, changes in the balance of organisms, and water quality degradation" (Ferreira et al., 425 2010). According to the MSFD, GES is achieved with respect to eutrophication when "Human426 induced eutrophication is minimised, especially adverse effects thereof, such as losses in 427 biodiversity, ecosystem degradation, harmful algae blooms and oxygen deficiency in bottom 428 waters" (MSFD, 2008/56/EC, Annex I).

In coastal environments, eutrophication means the increase of primary production generally 430 monitored through the chlorophyll- $a(\mathrm{Chl} a)$ content and/or macroalgal biomass (Ferreira et al., 431 2007; Xiao et al., 2007; Borja et al., 2008; Bricker et al., 2008; Nixon, 2009). The effects of 432 eutrophication are the lowering of oxygen concentrations, losses of submerged aquatic 433 vegetation, and mass mortalities especially at the sediment water interface (Claussen et al., 2009; 434 Ferreira et al., 2011). The global occurrence and expansion of hypoxic/anoxic events at bathyal 435 depths worldwide point to the need for better understanding and monitoring of the effects of 436 such phenomena on deep-sea benthic communities (Doya et al., 2015; Breitburg et al., 2018). 437 Recent models foresee an oxygen decline from 1 to $7 \%$ in the next 100 years (Keeling et al., 2010) 438 with an increase in the extension of Oxygen Minimum Zones (OMZs) (Stramma et al., 2008). 439 Farther, OMZs, with their naturally occurring low pH and oxygen, offer some hints as to the 440 structure of deep-sea ecosystems affected by eutrophication (Levin, 2003; Moffit et al., 2015). Deep-sea ecosystems have been historically considered as a food-poor environment, and 442 this is typically true for the deep Mediterranean Sea, especially in its eastern basin, but some areas 443 may experience symptoms of eutrophication and oxygen depletion (Danovaro et al., 2014). For 444 instance, it has been reported that massive phytodetritus exports from highly productive coastal 445 waters to the deep-sea floor (Billet et al., 1983). Excessive $C$ inputs in combination with the high 446 bottom temperatures can cause episodic oxygen depletion in the deep sea (Ferreira et al., 2011; 447 Danovaro et al., 2014). Recent studies highlighted that deep-sea trophic status can be also 448 affected by climate change, as the Western basin is expected to become more oligotrophic and 449 the Eastern basin more eutrophic (Piroddi et al., 2017). In addition, predicted increasing surface 450 temperatures may affect water mass stratification and the formation of cold oxygenated deep 451 water, modifying global ocean circulation and the dissolved oxygen availability in deep-water 452 masses (Ramirez-Llodra et al., 2011). Local scale eutrophication could affect deep-sea sediments 
453 facing highly productive areas of the Mediterranean Sea, such as the Gulf of Lions, the northern 454 Aegean Sea and the Ionian Sea receiving inputs from the Adriatic Sea.

However, the MSFD, in relation to the qualitative Descriptor 5, calls for an assessment of 456 nutrients and organic matter inputs (Annex III of Directive 2017/845) and the use of the following 457 criteria (Directive 2017/848): i) nutrient concentrations in the water column, ii) chlorophyll a in the 458 water column, iii) harmful algal blooms, iv) photic limit, v) dissolved oxygen at the bottom of the 459 water column, vi) opportunistic macroalgae, vii) macrophyte communities and viii) macrofaunal 460 communities. These criteria can only be partially applied to the deep sea. Firstly, primary 461 producers (e.g., macrophyte, macroalgae, harmful algal bloom) must be excluded, and the assessment of trophic status using variables measured in the water column can lead to misleading 463 classifications (Dell'Anno et al., 2002, see also Fabri et al., 2018). Considering that oxygen 464 depletion is one of the main causes of benthic faunal mortality, it is important to measure include i) quantity and quality of sedimentary organic matter, and ii) biodiversity and taxonomic 476 composition of benthic invertebrates (Dell'Anno et al., 2002; Pusceddu et al., 2009, 2011, 2014; Bianchelli et al., 2016a). Among indicators recently proposed to assess benthic trophic status of 
485 lead to responses from all benthic components, from prokaryotes to foraminifera, and from 486 meiofauna to macrofauna (Danovaro et al., 1999). Also the functional traits of macrofauna have 487 been widely used as indicators of alteration and for measure the health status of marine benthic 488 ecosystems (Borja et al., 2008). Further, meiofauna could be considered a good indicator as it is 489 highly sensitive to environmental changes, and particularly to organic enrichment due to 490 eutrophication (Pusceddu et al., 2011). For these reasons, meiofauna have been recently proposed 491 for the monitoring of eutrophication effects and for assessing the environmental quality of both 492 coastal and deep-sea ecosystems (Bianchelli et al., 2016a; Pusceddu et al., 2016).

493

\subsection{Descriptor 6: Sea floor integrity}

Descriptor 6 requires that seafloor integrity is "at a level that ensures that the structure and 496 functions of the ecosystems are safeguarded and benthic ecosystems, in particular, are not 497 adversely affected" (Commission Decision 2010/477/EU). This involves addressing "physical 498 damage, having regard to substrate characteristics", and the "condition of benthic community", 499 the latter being directly related to Descriptor 1. The relevant pressures identified in the 500 Commission Decision (EU) 2017/848 generically refer to "physical loss (due to permanent change 501 of seabed substrate or morphology and to extraction of seabed substrate)" and to "physical 502 disturbance to seabed (temporary or reversible)". Four primary criteria address these points, three 503 of which (D6C1 to DGC3) are specific for Descriptor 6, while two are also relevant for Descriptor 1 504 (D6C4 and D6C5).

505 The deep Mediterranean seafloor experiences two dominant physical disturbances 506 associated with human activities: i) bottom-contact fisheries and ii) oil and gas activities (Boschen 507 et al., 2013; D'Onghia et al., 2017; Lauria et al., 2016; Holler et al., 2017). Fisheries using bottom508 contacting gear lead to direct alteration of seafloor morphology at large, medium and small scales 509 (Puig et al., 2012; Martin et al., 2014). Bottom trawling is a key driver for large-scale seascape 510 change as it smoothens the natural topography (Puig et al., 2012). Direct and indirect biological 511 effects of bottom trawling have been demonstrated in terms of biogeochemical changes (e.g. less 512 total amino acid concentration in sediments) and faunal desertification (Pusceddu et al., 2014). 513 The Mediterranean Sea shows the highest fisheries footprint per unit landings in Europe (Eigaard 514 et al., 2017), with peak intensities in the Tyrrhenian and the Adriatic Sea. In the Catalan margin, 515 trawling impact is major down to $800 \mathrm{~m}$ depth (Puig et al., 2012). Sediment resuspension from 516 fishing grounds can propagate to wider and deeper areas eventually leading to suffocation and 
517 burial of VME (Martin et al., 2008). Downslope moving gravity-driven resuspension flows enhance 1008518 sedimentation rates far beyond fishing grounds, such as in canyon axes. Other types of fishing gear such as bottom touching longlines and gillnets could also have a significant adverse impact on vulnerable benthic communities and organisms such as black corals, gorgonians, scleractinians and many other habitat-forming species (GFCM, 2017), because of breaking while pulling, ghost fishing or entanglement.

Activities undertaken by the offshore oil and gas industry may cause physical loss of the natural deep seabed. Physical (and chemical) impacts on the seafloor and subseafloor range from the installation of drilling rigs, wellheads and other structures on the seabed to the accumulation of litter including lost or abandoned equipment, consumables and other materials. Today's deepwater $(>200 \mathrm{~m}$ ) oil and gas production in the Mediterranean Sea, or advanced prospects for it, takes place essentially offshore Egypt, Israel, Lebanon, Syria and Cyprus (The Petroleum Economist Ltd, 2013; Galil and Herut, 2011). The environmental approach for the hydrocarbon industry in the Mediterranean Sea is developed in the Offshore Protocol of the Barcelona Convention, adopted in October 1994, which obliges countries to perform comprehensive EIAs after entering into force in December 2012. The EU adopted the Directive on Safety of Offshore Oil and Gas Prospection, Exploration and Production Activities in July 2013, which provides a blueprint of the best international practice also for non-EU countries in the Eastern Mediterranean that are new to the energy industry (Livnat, 2014). Further disturbance occurs in case of cable deployment, for not the cables and pipelines per se, rather for the impact of the anchoring of the supply vessel during the deployment of the cable.

Dumping of industrial waste in the deep Mediterranean Sea is a matter of concern for habitat integrity. Submarine canyons with heads close to the coast are favoured sites for direct deep-sea disposal (Ramirez-Llodra et al., 2015). Two aluminium-processing plants have discharged red mud waste in the deep Mediterranean Sea: one in France (Cassidaigne Canyon, Gulf of Lion) (Dauvin, 2010; Fontanier et al., 2012, 2014; see also Fabri et al., 2018) and one in Greece (Gulf of Corinth, Antikyra Bay) (Varnavas et al., 1986; Varnavas and Archilleopoulos, 1995; Poulos et al., 1996). Since 1988, Coal Fly-Ash (CFA) from the Hadera power plant, in Israel, has been dumped into a $16 \mathrm{~km}^{2}$ disposal site some $70 \mathrm{~km}$ offshore, at a water depth of $1400 \mathrm{~m}$, where a $0.5-1.0 \mathrm{~cm}$ thick ash layer has been noticed (Kress et al., 1996, 1998) together with severe impoverishment of benthic fauna. Israel allowed also long-term disposal of dredged sediments and industrial waste 
$548\left(1,900,000 \mathrm{~m}^{3}\right)$ polluted with $\mathrm{Hg}, \mathrm{Cd}, \mathrm{Pb}$, tributyltin and organotins, and PCBs at a site $1300 \mathrm{~m}$ deep 1067549 (Herut et al., 2010).

Different proved tools is currently available to assess seafloor integrity. High-resolution

maps of benthic substrata and habitats are increasingly required both to underpin environmental and socioeconomic impact assessments and to help in developing effective management measures (Kenny et al., 2003; Brown et al., 2011; Stephens and Diesing, 2014; Holler et al., 2017; Fabri et al., 2018). Multibeam Echo-Sounders (MBES) and side scan sonars (SSS), map seabed areas with $100 \%$ spatial coverage at a resolution finer than $1 \mathrm{~m}^{2}$, depending on the depth of data collection and on distance-to-bottom of the sensors (Kenny et al., 2003). Ground-truthing methods, such as the use of remotely operated vehicles (ROVs) and autonomous underwater vehicles (AUVs) (Fabri et al., 2014; Lastras et al., 2016), are widely available and could be applied according to the size and the nature of the area of interest (Kenny et al., 2003; Brown and Blondel, 2009; Brown et al., 2011; Holler et al., 2017). Habitat suitability models try to predict the distribution of some habitats such as CWCs (Lo lacono et al., 2012; Bargain et al., 2017, 2018; Fabri et al., 2017; Angeletti et al., 2019; Lo lacono et al., 2018; Giusti et al., 2014, 2017; Lauria et al., 2017). However, because such models often include a large degree of uncertainty, decisions based entirely on modelling approaches may involve significant risk.

The revision of the MSFD (through the COMM. DEC. 2017/848/EU) emphasised that "Physical loss shall be understood as a permanent change to the seabed which has lasted or is expected to last for a period of two reporting cycles (12 years) or more", but for this to be implemented, a very long time perspective is needed. All impacts described in this section have immediate effects (and sometimes also delayed effects) on seafloor communities, which in most cases could represent either a tipping point (e.g. large-scale seascape change) or require long time before any significant recovery could take place. A time-span of 12 years is possibly too short and it is urgent to proceed with a sound extensive evaluation of the current status of the deep benthic habitats in the Mediterranean Sea before human impact severely modifies or erases them from the face of our planet.

\section{Descriptor 7: Permanent alteration of hydrographical conditions}

Descriptor 7 is geared towards addressing the problem of the permanent alteration of hydrographical conditions. These conditions are often affected by the presence of coastal 579 infrastructure and other man-made activities (ports, artificial reefs, etc.). However, in most cases 
these structures impact coastal areas and only rarely can reach higher depths. Conversely, global climate change, combined with episodic climate-driven events, can alter the "hydrographical conditions" also at depths. In recent decades, deep Mediterranean waters have experienced drastic changes resulting in an alteration of the stratification associated to temperature increases and salinity shifts (Schroeder et al., 2009, 2016). At the end of the 1980s, climate change, changing hydrographic properties, surface circulation, and deep-water convection caused a 'regime shift' on a global scale (Reid et al., 2016) and throughout the Mediterranean basin (Conversi et al., 2010). During that period, the main site of deep-water formation shifted from the southern Adriatic to the Aegean sub-basins. This "Eastern Mediterranean Transient" (EMT; 1987-1994) event resulted in increased oxygen consumption (Roether and Well, 2001; Klein et al., 2003) and, in the eastern Ionian, in a nutricline shoaling by about $150 \mathrm{~m}$ (Klein et al., 1999). Other rapid hydrological changes have also occurred in the Western Mediterranean Sea. The "Western Mediterranean Transient" (WMT; 2004/05 and 2005/06) was characterised by the formation of warmer and denser new deep waters over the continental shelf as a result of cooling and evaporation of the surface layer and downslope cascading (Canals et al., 2006; Palanques et al., 2006; Schroeder et al., 2009). The high volumes of newly formed deep waters generated during intense cascading and convection events dramatically altered the hydrological structure of the basin, completely destratifying the water column and transferring massive heat and salt to the deep layers (Canals et al., 2006; Schroeder et al., 2009; Martin et al., 2010). The 2004/05 event was the first of a series of similar events in the last decade that greatly altered the structure of the intermediate and, especially, the deep layers of the Western Basin (Durrieu de Madron et al., 2013). Cascading events transport huge amounts of nutrients and organic matter, to bathyal depths (Canals et al., 2006; Sanchez-Vidal et al., 2008; Danovaro et al., 1999; Company et al., 2008). Hydrographic preconditioning (heat and salt content and structure of the water column before the onset of convection), and atmospheric forcing (heat, freshwater and buoyancy fluxes) triggered deep-water formation (Fabri et al., 2018). Moreover, progressive increase in heat and salt content in the intermediate layer, advected from east to west, favoured new dense water formation in the North-Western Mediterranean basin. Multiple heat and saline anomalies characterised the Mediterranean Sea from 1950 to 2000 (Rixen et al., 2005; Kress et al., 2014) and although these alterations cannot be considered permanent, all of these changes have long-term effects.

The multidisciplinary Mediterranean Targeted Projects MTP-I and MTP-II/MATER (19932000; Monaco and Peruzzi, 2002), the MEDAR/MEDATLAS database (Fichaut et al., 2003), the 
612 SeaDataNet (i.e., https://www.seadatanet.org/) and EMODnet (http://www.emodnet-physics.eu)

infrastructures created datasets on temperature, salinity oxygen, silicate, nitrates and phosphates,

614 but in some cases with insufficient coverage in the eastern region (including Tunisia, Libya, Croatia 15 and Turkey; Simoncelli et al., 2015).

Since the 2000's, national and international programmes (e.g. EU-PERSEUS and MedSeA, IT-

VECTOR, FR-MERMEX, E-RADMED) produced hydrological data on the whole Mediterranean Basin. 618 Regular cruises, mooring lines, and deployment of new instruments and infrastructure (Argo 19 floats, gliders) now support intensive collection of in situ observations in the North-Western Mediterranean Sea. Argo floats, autonomous profiling floats, drift at a given depth for a given time period. After drifting for a set time, they sink to $2000 \mathrm{~m}$ and profile temperature and salinity during the upcast. These data proven useful in describing deep-water formation (Smith et al., 2008). Moreover, in the last decade, glider technology mainly in the North-Western Mediterranean Sea has enabled repeated cross-basin transects at depths from the surface to 1000 m. In addition, numerical models implemented at regional or local scales use these data to elucidate water mass formation and spreading, and basin-scale hydrological dynamics (Bonaldo et al., 2015; Estournel et al., 2005).

Long-term monitoring of basic hydrological parameters (temperature and salinity), collected as time series with appropriate temporal resolution (i.e. sampling intervals that resolve all relevant timescales) represent a science priority in the context of climate change study for key locations in the Mediterranean Sea (e.g. straits and channels, zones of dense water formation and spreading, deep basins) (Schroeder et al., 2013; Aguzzi et al., 2019). The HYDROCHANGES network aims to address this need by deploying moorings fitted with Conductivity, Temperature, Depth sensors (CTDs) at key locations for monitoring temperature and salinity (Schroeder et al., 2013). The FixO3 635 (Fixed point Open Ocean Observatory network, http://earthvo.fixo3.eu/) programmes and the EMSO (European Multidisciplinary Seafloor and water column Observatories, http://emso.eu/) EU continuously monitor sets of specific parameters. Long time series provided by these mooring stations have contributed pivotal findings on the deep dynamics of the Mediterranean Sea in last 642 years. In order to partially interpolate data within homogeneous habitats, scientists have generated gridded products through objective analysis of available observations (such as 
644 numerical models with data assimilation delivered by Copernicus downstream services (http://marine.copernicus.eu/services-portfolio/access-to-products/).

\subsection{Descriptor 8: Concentrations of contaminants giving rise to pollution effects}

The input of xenobiotic substances represent one of the major threats for ocean health (Halpern et al., 2008). Hydrophobic pollutants, such as organo-halogenates and polycyclic aromatic hydrocarbons (PAH), enter the marine environment through effluent discharges, atmospheric deposition, runoff and other means (Iwata et al., 1994). Once in the water column, the adsorption onto particulate matter transfers these compounds from the surface to the deep waters and sediments (Buesseler, 1998). Particle settling is also favoured by biological processes, and by lateral transport from continental shelves (Heussner et al., 2006; Martin et al., 2006; Zuñiga et al., 2009). DSWC is a massive mechanism of pollutant transfer to the open deep ocean (Canals et al., 2006). Higher fluxes of organohalogen pollutants and Polycyclic Aromatic Hydrocarbons (PAH) occur during these cascading events (Salvadó et al., 2017). PAH settling fluxes in the northwestern Mediterranean Sea vary widely (Lipiatou et al., 1993; Raoux et al., 1999), with highest concentrations of contaminants in the Alboran Sea (Dachs et al., 1996), and much lower values in 660 Sardinia and in the Southern Ionian Sea (Bouloubassi et al., 2006; Tsapakis et al., 2006). However, Mediterranean Sea, thus highlighting the role of river discharge (Heussner et al., 2006; Bonnin et al., 2008; Palanques et al., 2008). Qualitative differences are also observed in relation to these transfer processes. Sediments of coastal areas, continental shelves and slopes have higher proportions of petrogenic PAHs whereas the deep basin of the north-western Mediterranean Sea is characterized by high amounts of pyrogenic PAHs.

Organochlorine compounds such as Polychlorobiphenils (PCBs) and chlorinated pesticides, characterised a group of Persistent Organic Pollutants (POPs) of worldwide concern due to their toxic effects (Harmon, 2015). Notwithstanding the discontinued use of these compounds in most world areas, thanks to relevant national regulations and international agreements such as the Stockholm Convention, their extensive occurrence is still observed, Their high lipophilicity, hydrophobicity, chemical stability and resistance to biological degradation have led to their accumulation in biological tissues and biomagnification through the food chain.

Radioactive compounds in the Mediterranean Sea are derived from the fallout of nuclear weapon testing and the Chernobyl accident. In sediments, concentrations of ${ }^{137} \mathrm{Cs}$ and ${ }^{239+340} \mathrm{Pu}$ 
676 have been measured in various parts of the Mediterranean Sea, including deep basins. The concentrations are generally higher in coastal ecosystems because land-based sources can exceed

678 atmospheric inputs (Durrieu de Madron et al., 2011; Garcia-Orellana et al., 2009). Concentrations in biota are presently undistinguishable from those in areas without point sources. Hence, the relevance of these contaminants lies in their usefulness as process tracers, more than on their impact on the environment. Studies on radionuclides in marine organisms also underscore that the radionuclide levels are constantly decreasing due to modifications of the inputs. Very little work has been done to examine the trophic transfers of man-made radionuclides (Harmelin-Vivien et al., 2012). Finally, neglected impacts that can be very important in several areas of world are military activities. Information on their impacts on the environment are relatively scarce and are often studied after several years from their production and without any baseline available (Lawrence et al., 2015; Danovaro et al., 2019).

Atmospheric inputs constitute one of the major sources of Trace Elements (TE) to the deep Mediterranean Sea (Migeon et al., 2012; Guerzoni et al., 1999), where TE concentrations in waters are typically higher than in other areas of the world ocean. In addition, $\mathrm{Cd}, \mathrm{Cu}$ and $\mathrm{Ni}$ (as well as $\mathrm{Cr}$ ) are dominated by lateral advection and vertical mixing rather than by biogeochemical cycling (Morley et al., 1997). The hydrologic regime of the Mediterranean Sea tends to transfer the pollutants and nutrients to the Atlantic by bottom water flow transport. Our knowledge on the concentrations, fluxes, and behaviour of trace elements, radionuclides and organic substances in the deep waters and sediment and their toxicological impacts on habitats and organisms is scarce (Durrieu de Madron et al., 2011). Pollutants with hydrophobic properties, e.g. PCBs and mercury, accumulate in biota and thus in the food web. In case of chronic pollution events, the concentration of contaminants should be analysed in sediments collected by sediment cores, which enable the reconstruction of temporal trends. Sample collection of water at different depths and analysis of the dissolved and particulate matter would also be important. Abundance of populations and estimates of the extent of habitats adversely affected by chronic pollution should be assessed concurrently.

Nonetheless, information on pollutants in the deep sea is almost completely lacking, and this represent the main gap in the application of the criteria needed to determine the D8.

\subsection{Descriptor 9: Contaminants in fish and other seafood for human consumption}


Descriptor 9 focuses on the accumulation of toxic, persistent and liable substances in wild deep-sea organisms used for human consumption (i.e., mostly teleost and decapod crustaceans)

and the contaminants considered by D9 are only part of those of interest for the D8 (cfr.

Regulation EC 1881/2006 and its amendments EC 2006, 2008). Each Member State may ignore specific contaminants and/or include additional ones (EC 2017) (Fliedner et al., 2018). In any case the monitoring of the contaminants accumulated in the deep-sea biota should at least consider the following compounds for which regulatory levels have been set: i) heavy metals (lead, cadmium and mercury); ii) PAHs; iii) dioxins (including dioxin-like PCBs). In addition, the following contaminants of relevance should be monitored: i) non-dioxins like PCBs; ii) phthalates; iii) organochlorine pesticides; iv) organotin compounds; v) brominated flame retardants; vi) polyfluorinated compounds. Also, artificial radionuclides should be monitored in case of nuclear accidents or any other radioactive emergencies that could lead to or has led to significant radioactive contamination of food.

Contaminants in fish and other seafood might derive from numerous anthropogenic

sources described for the D8. Chemical contamination in fish and seafood results from a complex process that balances inputs of contaminants, mostly through diet, and their excretion (Solé et al., 2001; Trudel and Rasmussen, 2001; Cresson et al., 2014).

Investigating contamination levels in fish and seafood requires understanding which

contaminants exceed regulatory limits, how much they alter food webs, and what metabolic processes are involved in detoxification. The presence of xenobiotics in the deep Mediterranean organisms has been repeatedly documented (Galil et al., 1995; Storelli et al., 2009) with deep-sea Mediterranean fishes tending to exhibit higher levels of metal accumulation than those of populations inhabiting other areas such as the Atlantic Ocean (Damiano et al., 2011). Red-shrimps, Aristeus antennatus and Aristaeomorpha foliacea may be useful indicator species of levels of deep-sea contamination (e.g., see data on A. antennatus, Koenig et al., 2012). Contaminants in fish muscle and liver have been investigated in the most abundant deep-sea megafaunal species, e.g.

Alepocephalus rostratus, Coelorinchus mediterraneus, Coelorhinchus caelorhincus, Trachyrincus trachyrincus and Nezumia sclerorhynchus, Chimaera monstrosa, Lophius budegassa, Lepidion lepidion (Koenig et al., 2013c), revealing mercury concentration exceeding $0.5 \mu \mathrm{g} \mathrm{g}^{-1}$ muscle wet 
739 Coquery, 2005; Cossa et al., 2012). The Hg concentration is even higher in some deep-sea fish 1421740 species (Koenig et al., 2013c; Cresson et al., 2014; Chouvelon et al., 2018). Most deep-sea species

741 are long-lived and slow-growing, which favours the bioaccumulation of pollutants (Drazen and

\subsection{Descriptor 10: Marine litter}

Two primary and two secondary criteria are associated to Descriptor 10: i) the composition, amount and spatial distribution of litter (D10C1) and of micro-litter (D10C2) "on the coastline, in the surface layer of the water column, and on the seabed, are at levels that do not cause harm to the coastal and marine environment" (primary) and ii) the amount of litter ingested by marine animals, which should not reach a level that adversely affect the health of the species (D10C3) and the number of individuals which are adversely affected due to litter, such as by entanglement, other types of injury or mortality, or health effects (D10C4) (secondary). Each sub-region should assess the outcomes for all criteria and as well as threshold values.

Marine litter represents a threat for the health of the deep Mediterranean Sea due to its 767 heavy maritime traffic (UNEP, 2015). The sources of marine litter to the deep-sea floor of the 768 Mediterranean Sea are either from land (river discharge, storm drains, sewage treatment plants 769 and industrialized areas) or marine (fishing activities, commercial and recreational shipping, 770 aquaculture, direct dumping), and include plastics (accounting for $>70 \%$ of the total), glass, metal, 
771 clinker, cardboard and fabrics (Galgani et al., 2000; Ramirez-Llodra et al., 2013; Fabri et al., 2014;

Pham et al., 2014; Tubau et al., 2015; UNEP, 2015; Mecho et al., 2017). The quantity and composition of marine litter differs among regions and changes with depth, probably as a result of a complex set of interactions between hydrodynamics, geomorphology, and anthropogenic sources (Pham et al., 2014; Tubau et al., 2015; UNEP, 2015). The abundance of marine litter items in the deep Mediterranean Sea varies from 500 items km-2 on the continental slopes off Malta and Cyprus (Mifsud et al., 2013; loakeimidis et al., 2014), the Tyrrhenian Sea (Angiolillo et al., 2015), or the Adriatic Sea (Galgani et al., 2000), to more than 2,000 items $\mathrm{km}^{-2}$ in the Antalya Bay in the Eastern Mediterranean or in the submarine canyons of the Gulf of Lion and of the Catalan Sea (Galgani et al., 2000; Tubau et al., 2015). Astonishingly high litter abundance of up to 1.3 million of items $\mathrm{km}^{-2}$ were reported at $300-600 \mathrm{~m}$ depth in the Messina Strait canyons (Central Mediterranean Sea) (Pierdomenico et al., 2019). Litter abundance found in submarine canyons and depths greater than $500 \mathrm{~m}$ typically exceeds that at shallower depths, suggesting that submarine canyons can act as primary conduits of litter from the coast to the deep sea (Galgani et al., 2000; Tubau et al., 2015). Superposition of highly efficient source-to-sink sedimentary transport (with flash-flood generated hyperpycnal flows) and strong urbanization of the coastal area promote the occurrence of large litter hotspots in the deep sea (Pierdomenico et al., 2019). In addition to large marine debris, concern has grown about microplastics (i.e., $<1-5 \mathrm{~mm}$ in diameter; Desforges et al., 2014), which can directly enter the ocean also through cosmetic abrasives (i.e. microbeads), preproduction plastic pellets, or textile fibres known as primary plastics. Additionally, combined mechanical, biological, photic and thermal actions can break down larger plastic objects into numerous small fragments, which are defined as secondary microplastics. Depending on the density of the polymer, microplastics may sink and behave as very fine-grained sediments (for example polyester; Woodall et al., 2014), or they may float and subsequently sink following colonization by organisms, adsorption to phytoplankton, and/or aggregation with organic debris. 796 Fibres appear to dominate the microplastics reported in Mediterranean deep-sea sediments (van 797 Cauwenberghe et al., 2013; Woodall et al., 2014; Sanchez-Vidal et al., 2018). Recent studies effects of large and small items include entanglement, ingestion, colonization and rafting (Gregory, 
2009; Murray and Cowie, 2011; Anastasopoulou et al., 2012; Ramirez-Llodra et al., 2013; Bo et al.,

2014; Pham et al., 2014; Angiolillo et al., 2015; Tubau et al., 2015). However, information on the

actual effects of (micro)plastics on deep-sea organisms and trophic webs is still limited (Taylor et al., 2016).

Marine litter in deep sea produces economic impacts primarily on the fishery sector, damaging vessels and fishing equipment due to entanglement of catch, loss of target species through ghost fishing, or reduced reproductive capacity of benthic organisms consuming microplastics (Newman et al., 2015). Furthermore, marine litter may contain pollutants (hazardous plastic additives, POPs) that exert toxic and endocrine disruptive effects on marine organisms that ingest plastics (Oehlmann et al., 2009).

\subsection{Descriptor 11: Introduction of energy including underwater noise}

Descriptor 11 deals with introduction of energy into the marine environment. Underwater noise can be pulsed or continuous. MSFD currently focuses on two criteria: anthropogenic pulsed (D11C1) and continuous low-frequency (D11C2) sounds in water. D11C1 addresses the space-time distribution of pulsed noise sources, whereas D11C2 addresses levels of continuous noise, using in situ measurements and models. Pulsed noise may cause direct acute effects such as hearing loss, tissue damage, and death of individuals of sensitive species such as cetaceans. Whereas continuous or chronic noise exposure mainly causes stress and behavioural alterations, with negative effects on deep-sea organisms (Nowacek et al., 2015). The proposed strategy on noise

823 monitoring recommends several adaptations in the case of the deep Mediterranean. Particularly, both indicators are closely related to the acoustic biology of deep-diving marine mammal species, such as sperm whale and Cuvier's beaked whale. Pulsed noise can be monitored by setting up a 826 register of anthropogenic activities, reporting on date, location, proportion of days within a given period and over a given geographical scale in which activities generating pulsed sounds occur. This subsequent future development into larger geographic network: Rountree et al., 2019).

A variety of phenomena generates noise in the ocean, either from physical processes, such 832 833 whale songs, dolphin clicks, and fish vocalizations (Montgomery and Radford, 2017); not all reach 834 the deep sea. Fish produce sounds for their navigation, habitat selection and mating, as well as to 
communicate (Simpson et al., 2005). Marine mammals use sound as a primary tool for underwater communication (Wartzok and Ketten, 1999), mating and social interaction (Edds-Walton, 1997), 837 and for tracking the prey (Au, 1993).

Anthropogenic noise can reach the deep sea, through commercial shipping, oil and gas exploration, fishing, and scientific research; all of these sources currently contribute to the general noise budget of the ocean (Montgomery and Radford, 2017). The impact of noise on marine is being increasingly investigated (Wenz, 1962; Hildebrand, 2009). Noise sources are divided into three frequency bands: low (10 to $500 \mathrm{~Hz}$ ), medium (500 Hz to $25 \mathrm{kHz}$ ) and high (>25 kHz). Anthropogenic sources dominate the low-frequency band, and include commercial shipping and seismic emissions for hydrocarbon exploration. Minimal attenuation of low-frequency sound allows long-distance propagation. Sea-surface agitation (breaking waves, spray, bubble formation and collapse, and rainfall) and various sonars (e.g. military and multibeam seabed mapping), as well as small vessels produce most medium frequency sound. Greater attenuation limits propagation of noise in the mid-frequency band over long distances, and only local or regional (10s of km distant) sound sources contribute to this ambient noise field. At high frequencies, extreme acoustic attenuation confines all noise sources to the area close to the receiver.

Oil industry operations have traditionally focused on shallow, continental shelf waters, but exploration is moving in deeper waters (>500-1000 m). Expansion of oil exploration into deeper water has increased the potential for long-range propagation of seismic reflection signals. Indeed, sound in deep waters can propagate greater distances than in shallow-water ecosystems, by moving through the deep sound channel (Hildebrand, 2009). Seismic surveys currently target all regional seas in the south-eastern Mediterranean, apart from the Aegean Sea (Maglio et al., 2016). 857 This expansion stresses the transboundary aspect of seismic surveys and calls for international 858 cooperation.

860 and stress, especially in marine mammals, sea turtles and fish (Popper et al., 2014; Peng et al., 861 2015). The occurrence of low frequency noise in the deeper part of the basins is particularly 863 they use as a background for echolocation decreases rapidly with depth (Foote et al., 2004; André 864 et al., 2011; Azzellino et al., 2011). Indeed, small odontocetes produce high frequency sounds 865 (ranging from $70 \mathrm{kHz}$ to more than $150 \mathrm{kHz}$ ), while sperm whales, Physeter macrocephalus, during diving, make sound with frequencies ranging to more than $30 \mathrm{kHz}$ which are detectable within 10- 
$15 \mathrm{~km}$. The fin whale Balaenoptera physalus, the only mysticete constantly present in the

Mediterranean Sea, emits mostly infrasonic signals $(20-40 \mathrm{~Hz})$, which are emitted in long

sequences and can be detected at large distances.

Research on sea turtles in the South-Eastern Mediterranean region revealed that they can detect low frequency sounds that overlap with seismic airgun frequencies, these are high-

872 intensity, low-frequency impulsive noise at regular intervals, mostly between 10 and $300 \mathrm{~Hz}$ 873 (Carroll et al., 2017; Nelms et al, 2016). Airguns can stress the sea turtles, Caretta caretta 874 (DeRuiter et al., 2012). The impacts of anthropogenic noise on sharks and rays are poorly studied, with most research to date focusing outside the Mediterranean region (Weilgart, 2017). Fish sensitivity to certain frequencies varies among species (Carroll et al., 2017). Recent studies demonstrate negative effects of seismic survey airgun operations even in zooplankton (McCauley et al., 2017).

In situ acoustic measurements can document continuous low-frequency sound, gathering field data on ambient noise in a given location. Understanding the large-scale influence of artificial noise on marine organisms and ecosystems represents the main gap to the application of the D11 on the deep sea. Deep-sea observatories offer new opportunities to assess the presence and effects of noise in on deep-sea life (Aguzzi et al., 2019). Deep-sea cabled observatories (i.e. NEMOSN1 in the Western Ionian Sea, Caruso et al. 2015, Favali et al., 2013; ANTARES in the Ligurian Sea, André et al., 2017; and PYLOS in the South Ionian Sea, http://www.fixo3.eu/observatory/pylos/) 886 are equipped with hydrophones for passive acoustic monitoring. Besides these measurements, 887 and especially for monitoring continuous low-frequency sound in deep sea, modelling approaches (both for single sources or distributed sources of noise, from the most advanced Dynamic Ambient Noise Prediction System elaborated by the U.S. for modelling multiple sources, to the Acoustic Integration Model used for modelling the effects of noise on cetaceans; NRC, 2003) may reduce the time required to establish trends and patterns.

\section{3. Future implementation}

895 achieve or maintain GES in open waters and deep-sea bottoms, including "spatial protection 896 measures, contributing to coherent and representative networks of marine protected areas, 897 adequately covering the diversity of the constituent ecosystems, such as special areas of conservation pursuant to the Habitats Directive, special protection areas pursuant to the Birds 
Directive, and marine protected areas as agreed by the Community or Member States concerned in

\section{8/56/EC, Article 13).}

The MSFD takes an overarching and integrated approach by focusing on achieving GES and targets, and we therefore recommend exploring and assessing synergies between the different treaties, directives, and conventions (e.g. see Descriptor 6 section) so that, wherever possible, the programme of measures and proposed MSFD monitoring simultaneously address the requirements of other legislations.

Our analysis indicates that the 11 Descriptors promulgated by the MSFD (MSFD, 2008/56/EC) can be adapted and applied to the deep sea. Several Descriptors (D1, D2, D3, D6, D8, D10) can be readily implemented, others (D4, D9 and D11) require additional data in order to set up benchmark and threshold values, while two (D5, D7) require changes in the assumptions and/or modification in the concept of "permanent".

Priority ecological variables, spatial distribution, extent of pressures and impacts ought to be identified and standardized in order to establish targets and indicators addressing the distinct conditions in the deep sea. The expertise, tools and resources required for deep-sea monitoring are not universally available to all Mediterranean Member States (MS), nor to countries in the southern and easternmost Mediterranean. These limitations may be overcome by initiating deep sea MDFD-focused monitoring in already data-rich locations (presumably off MS), and pioneering joint-effort monitoring in collaboration with non-MS, to enhance awareness, capacity building, 919 and gain much needed data on scantily studied regions. Given the costs entailed by scientific and technical expertise, tools and infrastructure required for deep-sea research and monitoring, we advocate for EU-level financial support for MS/non-MS collaboration spanning joint fieldwork, training (early career research fellowships, workshops) and public awareness communication.

Since the millennium, increased awareness of the vulnerability of deep-sea ecosystems has 924 changed attitudes concerning their protection and conservation (Ramirez-Llodra et al, 2011). Yet, 926 follows from basic scientific research and monitoring. Ecosystem-based management of the 927 Mediterranean deep sea pressingly requires comprehensive analysis of available data, new data 928 from yet unexplored regions, and impact assessment studies. Mounting evidence points to the 929 vulnerability of the deep biota to anthropogenic disturbance that may result in biodiversity loss, 
urgent implementation of the MSFD in the Mediterranean deep sea will go a long way towards conserving its unique biodiversity and habitats.

\section{Acknowledgements}

935

936

$\checkmark$ from University

BAMAR (ref.: CGL2016-81854-REDT), a network on marine litter, and RTD projects NUREIEV (ref. CTM2013-44598-R) and NUREIEVA (ref. CTM2016-75953-C2-1-R) on far-field and near-field impacts of the Portman Bay, SE Spain, coastal submarine mine tailings disposal site. Generalitat de Catalunya autonomous government funding to CRG Marine Geosciences (ref. 2017 SGR 315) within its support scheme to excellence research groups is equally acknowledged.

\section{References}

Aguzzi J., Bahamon N., 2009. Modeled day-night biases in decapod assessment by bottom trawling survey. Fisheries Research 100: 274-280.

Aguzzi J., Company J.B., Bahamon N., Flexas M.M., Tecchio S., Fernandez-Arcaya U., García J.A., Mechó A., Koenig S., Canals M. 2013. Seasonal bathymetric migrations of deep-sea fishes and decapod crustaceans in the NW Mediterranean Sea. Progress in Oceanography 118: 210-221.

Aguzzi, J., Fanelli, E., Ciuffardi, T., Doya, C., Kawato, M., Miyazaki, M., Furushima, Y., Costa, C., Fujiwhara, Y., 2018. Faunal activity rhythms influencing early community succession of an implanted whale carcass offshore Sagami Bay, Japan. Scientific Report, 8, 11163.

Aguzzi, J., Chatzievangelou, D., Marini, S., Fanelli, E., Danovaro, R., Flögel, S., Lebris, N., Juanes, F., De Leo, F., Del Rio, J., Thomsen, L.S., Costa, C., Riccobene, G., Tamburini, C., Lefevre, D., Gojak, C., Poulain, P.M., Favali, P., Griffa, A., Purser, A., Cline, D., Edigington, D., Navarro J., Stefanni, S., Company, J.B., 2019. New high-tech interactive and flexible networks for the future monitoring of deep-sea ecosystems. Env. Sci. Technol., 53(12), 6616-6631.

Allendorf, F.W., Berry, O., \& Ryman, N., 2014. So long to genetic diversity, and thanks for all the fish. Molecular ecology, 23(1), 23-25. 
960 961

Andradi-Brown, D. A., 2019. Invasive lionfish (Pterois volitans and P. miles): distribution, impact, and management. In: Loya Y., Puglise K., Bridge T. (eds) Mesophotic Coral Ecosystems. Coral Reefs of the World, vol 12. Springer, Cham, pp. 931-941.

Anastasopoulou, GA., Mytilineou, C., Smith, C., Papadopoulou, K., 2012. Plastic debris ingested by deep-water fish of the Ionian Sea (Eastern Mediterranean). Deep Sea Research I, 74, 11-13.

Anastasopoulou, A., Biandolino, F., Chatzispyrou, A., Hemida, F., Guijarro, B., Kousteni, V., Mytilineou, Ch., Pattoura P., Prato, E., 2016. New Fisheries-related data from the Mediterranean Sea (November, 2016). Mediterranean Marine Science, 17, 822-827.

André, M., Caballé, A., Van Der Schaar, M., Solsona, A., Houégnigan, L., Zaugg, S., and ANTARES consortium, 2017. Sperm whale long-range echolocation sounds revealed by ANTARES, a deep-sea neutrino telescope. Scientific Reports, 7, 45517.

André, M., Solé, M., Lenoir, M., Durfort, M., Quero, C., Mas, A., Lombarte, A., van der Schaar, M., Lopez-Bejar, M., Morell, M., et al., 2011. Low-frequency sounds induce acoustic trauma in cephalopods, Frontiers in Ecology and the Environment, 9, 489-493.

Angeletti, L., Bargain, A., Campiani, E., Foglini, F., Grande, V., Leidi, Mercorella, A., Prampolini, M., Taviani, M., 2019. Cold-Water Coral Habitat Mapping in the Mediterranean Sea: Methodologies and Perspectives. In: Mediterranean Cold-Water Corals: Past, Present and Future, C. Orejas, C. Jiménez (eds.), Coral Reefs of the World 9, Springer International Publishing AG, part of Springer Nature 2019. doi.org/10.1007/978-3-319-91608-8_16

Angiolillo, M., Lorenzo, B., Farcomeni, A., Bo, M., Bavestrello, G., Santangelo, G., Cau, A., Mastascusa, V., Sacco, F., Canese, S., 2015. Distribution and assessment of marine debris in the deep Tyrrhenian Sea (NW Mediterranean Sea, Italy). Marine Pollution Bulletin, 92, 149159.

Au, W.W.L., 1993. The sonar of dolphins. Springer-Verlag, New York.

Azzellino, A., Lanfredi, C., D’amico, A., Pavan, G., Podestà, M., Haun, J., 2011. Risk mapping for sensitive species to underwater anthropogenic sound emissions: model development and validation in two Mediterranean areas. Marine Pollution Bulletin, 63, 56-70.

Azzurro, E., Sbragaglia, V., Cerri, J., Bariche, M., Bolognini, L. Ben Souissi, J., Busoni, G., Coco, S., Chryssanthi, A., Fanelli, E., Ghanem, R., Garrabou, J., Gianni, F., Grati, F., Kolitari, J., Letterio, G., Lipej, L., Mazzoldi, C., Milone, N., Pannacciulli, F., Pešić, A., Samuel-Rhoads, Y., Saponari, L., Tomanic, J., Topçu, N.E., Vargiu, G., Moschella, P., 2019. Climate change, biological 
invasions, and the shifting distribution of Mediterranean fishes: A large-scale survey based

Bargain, A., Marchese, F., Savini, A., Taviani, M., Fabri, M.-C., 2017. Santa Maria di Leuca Province (Mediterranean Sea): Identification of suitable mounds for cold-water coral settlement using geomorphometric proxies and Maxent methods, Frontiers in Marine Science 4, 338, doi: 10.3389/fmars.2017.00338.

Bargain, A., Foglini, F., Pairaud, I., Bonaldo, D., Carniel, S., Angeletti, L., Taviani, M., Rochette, S., Fabri, M-C., 2018. Predictive habitat modeling in two Mediterranean canyons including hydrodynamics variables. Progress in Oceanography, 169, 151-168.

Bertrand, J., De Sola, L., Papaconstantinou, C., Relini, G., Souplet, A., 2002. The general specifications of the MEDITS surveys. Sci. Mar. 66, 9-17.

Béthoux, J.P., Gentili, B., 1996. The Mediterranean Sea, coastal and deep-sea signatures of climatic and environmental changes. Journal of Marine Systems, 7, 383-394.

Bianchelli, S., Danovaro, R., 2019. Meiofaunal biodiversity in submarine canyons of the Mediterranean Sea: A meta-analysis. Progress in Oceanography, 170, 69-80.

Bianchelli, S., Pusceddu, A., Buschi, E., Danovaro, R., 2016a. Trophic status and meiofauna biodiversity in the Northern Adriatic Sea: Insights for the assessment of good environmental status. Marine Environmental Research, 113, 18-30.

Bianchelli, S., Buschi, E., Danovaro, R., Pusceddu, A., 2016b. Biodiversity loss and turnover in alternative states in the Mediterranean Sea: a case study on meiofauna. Scientific Reports, 6 , 34544.

Bianchi, N., Morri, C., 2000. Marine biodiversity of the Mediterranean Sea: Situation, problems and prospects for future research. Marine Pollution Bulletti, 40, 367-376.

Bo, M., Bava, S., Canese, S., Angiolillo, M., Cattaneo-Vietti, R., Bavestrello, G., 2014. Fishing impact on deep Mediterranean rocky habitats as revealed by ROV investigation. Biological Conservation, 171, 167-176.

Bo, M., Bavestrello, G., Angiolillo, M., Calcagnile, L., Canese, S., Cannas, R., Cau, A., D'Elia, M., D'Oriano, F., Follesa, M.C. and Quarta, G., 2015. Persistence of pristine deep-sea coral gardens in the Mediterranean Sea (SW Sardinia). PloS One, 10(3), p.e0119393.

Bonaldo, D., Benetazzo, A., Bergamasco, A., Campiani, E., Foglini, F., Sclavo, M., Trincardi, F., Carniel, S., 2015. Interactions among Adriatic continental margin morphology, deep circulation and bedform patterns, Marine Geology, 375, 82-98. 
Bonnin, J., Heussner, S., Calafat, A., Fabres, J., Palanques, A., Durrieu de Madron, X., Canals, M.,

19521024

1953

19541025

1955

$1956^{1026}$

19571027

1958

19591028

1960

$1961^{1029}$

19621030

1963

19641031

1965

$1966^{1032}$

19671033

1968

19691034

1970

19711035

19721036

1973

19741037

1975

19761038

1977

$1978^{1039}$

19791040

1980

19811041

1982

$1983^{1042}$

19841043

1985

19861044

1987

$1988^{1045}$

19891046

1990

19911047

1992

$1993^{1048}$

19941049

19961050

1997

$1998^{1051}$

1999 $2000^{1052}$

20011053
Puig, P., Avril, J., Delsaut, N. (2008) Comparison of horizontal and downward particle fluxes across canyons of the Gulf of Lions (NW Mediterranean): Meteorological and hydrodynamical forcing. Continental Shelf Research, 28, 1957-1970.

Borja, A., Bricker, S.B., Dauer, D.M., Demetriades, N.T., Ferreira, J.G., Forbes, A.T., Hutchings, P., Jia, X.P., Kenchington, R., Marques, J.C., et al., 2008. Overview of integrative tools and methods in assessing ecological integrity in estuarine and coastal systems worldwide, Marine Pollution Bulletin 56, 9, 1519-1537.

Boschen, R.E., Rowden, A.A., Clark, M.R., Gardner, J.P.A., 2013. Mining of deep-sea seafloor massive sulfides: A review of the deposits, their benthic communities, impacts from mining, regulatory frameworks and management strategies, Ocean \& Coastal Management 84, Supplement C, 54-67.

Bouloubassi, I., Mejanelle, L., Pete, R., Fillaux, J., Lorre, A., Point, V., 2006. PAH transport by sinking particles in the open Mediterranean Sea: A 1-year sediment trap study. Marine Pollution Bullettin, 52, 560-571.

Breitburg, D., Levin, L.A., Oschlies, A., Grégoire, M., Chavez, F.P., Conley, D.J., Garçon, V., Gilbert, D., Gutiérrez, D., Isensee, K., Jacinto, G.S., 2018. Declining oxygen in the global ocean and coastal waters. Science, 359(6371).

Bricker, S.B., Longstaf, B., Dennison, W., Jones, A., Boicourt, K., Wicks, C., Woerner, J., 2008. Effects of nutrient enrichment in the nation's estuaries: A decade of change, Harmful Algae 8, 1, 21-32.

Brown, C.J., Blondel, P., 2009. Developments in the application of multibeam sonar backscatter for seafloor habitat mapping, Applied Acoustics, 70, 1242-1247.

Brown, C.J., Smith, S.J., Lawton, P., Anderson, J.T., 2011. Benthic habitat mapping: A review of progress towards improved understanding of the spatial ecology of the seafloor using acoustic techniques, Estuarine Coastal and Shelf Science, 92, 502-520.

Canals, M., Puig, P., Durrieu de Madron, X., Heussner, S., Palanques, A., Fabres, J., 2006. Flushing submarine canyons. Nature, 444, 354-357.

Carbery, M., O'Connor, W., Palanisami, T., 2018. Trophic transfer of microplastics and mixed contaminants in the marine food web and implications for human health. Environment International, 15, 400-409. 
Cardinale, M., Osio G.C., Scarcella, G., 2017. Mediterranean Sea: a failure of the European fisheries management system. Frontiers in Marine Science, 4, p.72, https://doi.org/10.3389/fmars.2017.00072.

Carlier, A., Le Guilloux, E., Olu, K., Sarrazin, J., Mastrototaro, F., Taviani, M., Clavier, J., 2009. Trophic relationships in a deep Mediterranean cold-water coral bank (Santa Maria di Leuca, Ionian Sea), Marine Ecology-Progress Series 397, 125-137.

Carroll, A.G., Przeslawski, R., Duncan, A., Gunning, M., Bruce, B., 2017. A critical review of the potential impacts of marine seismic surveys on fish \& invertebrates, Marine Pollution Bulletin 114, 9-24.

Cartes, J.E., Lolacono, C., Mamouridis, V., López-Pérez, C., Rodríguez, P., 2013. Geomorphological, trophic and human influences on the bamboo coral Isidella elongata assemblages in the deep Mediterranean: To what extent does Isidella form habitat for fish and invertebrates? Deep Sea Research Part I, 76, 52-65.

Cartes, J.E., Fanelli, E., Kapiris, K., Bayhan, Y.K., Ligas, A., López-Pérez, C., Murenu, M., Papiol, V., Rumolo, P., Scarcella, G., 2014. Spatial variability in the trophic ecology and biology of the deep-sea shrimp Aristaeomorpha foliacea in the Mediterranean Sea, Deep Sea Research Part I, 87, Supplement C, 1-13.

Caruso, F., Sciacca, V., Bellia, G., De Domenico, E., Larosa, G., Papale, E., Pellegrino, C., Pulvirenti, S., Riccobene, G., Simeone, F., and KM3NET Consortium, 2015. Size Distribution of Sperm Whales Acoustically Identified during Long Term Deep-Sea Monitoring in the Ionian Sea, Plos One 10, 12

Chimienti, G., Bo, M., Taviani, M., Mastrototaro, F., 2019. Occurrence and biogeography of cold water coral communities in Mediterranean hard and soft bottoms. In: Mediterranean ColdWater Corals: Past, Present and Future, C. Orejas, C. Jiménez (eds.), Coral Reefs of the World 9, Springer International Publishing AG, part of Springer Nature 2019.

Chouvelon, T., Cresson, P., Bouchoucha, M., Brach-Papa, C., Bustamante, P., Crochet, S., MarcoMiralles, F., Thomas, B., Knoery, J., 2018. Oligotrophy as a major driver of mercury bioaccumulation in medium-to high-trophic level consumers: A marine ecosystemcomparative study, Environmental Pollution 233, Supplement C, 844-854.

Claussen, U., Zevenboom, W., Brockmann, U., Topcu, D., Bot, P., 2009. Assessment of the eutrophication status of transitional, coastal and marine waters within OSPAR, Hydrobiologia 629, 1, 49-58, doi: 10.1007/s10750-009-9763-3. 
Coll, M., Piroddi, C., Kaschner, K., Ben Rais Lasram, F., Steenbeek, J., et al., 2010. The biodiversity of the Mediterranean Sea: Status, patterns and threats. PloS ONE. 5 (8): e11842. doi:10.1371/journal.pone.0011842.

Colloca, F., Cardinale, M., Maynou, F., Giannoulaki, M., Scarcella, G, Jenko, K., Bellido, J.M., Fiorentino, F. (2013). Rebuilding Mediterranean fisheries: a new paradigm for ecological sustainability. Fish and Fisheries, 14, 89-109. DOI: 10.1111/j.1467-2979.2011.00453.x

Company, J.B., Puig, P., Sarda, F., Palanques, A., Latasa, M., Scharek, R., 2008. Climate Influence on deep sea populations, Plos One 3, 1, e1431, doi: 10.1371/journal.pone.0001431.

Conese, I., Fanelli, E., Miserocchi, S., Langone, L., 2019. Food web structure and trophodynamics of deep-sea plankton from the Bari Canyon and adjacent slope (Southern Adriatic, central Mediterranean Sea). Progress in Oceanography 175, 92-104

Conversi, A., Fonda-Umani, S., Peluso, T., Molinero, J.C., Santojanni, A., Edwards, M., 2010. The Mediterranean Sea Regime Shift at the End of the 1980s, and Intriguing Parallelisms with Other European Basins, Plos One 5, 5, doi: 10.1371/journal.pone.0010633.

Coro, G., Vilas, L. G., Magliozzi, C., Ellenbroek, A., Scarponi, P., \& Pagano, P. (2018). Forecasting the ongoing invasion of Lagocephalus sceleratus in the Mediterranean Sea. Ecological Modelling, 371, 37-49.

Corsini-Foka M., Pancucci-Papadopoulo A., Kondilatos G., Kalogirou, S., 2010. Gonioinfradens paucidentatus (A. Milne Edwards, 1861) (Crustacea, Decapoda, Portunidae): a new alien crab in the Mediterranean Sea. Mediterranean Marine Science, 11, 331-340

Cossa, D., Coquery, M., 2005. The Mediterranean mercury anomaly, a geochemical or a biological issue. In: Saliot, A. (ed.) The Mediterraean Sea - The Handbook of Environmental Chemistry, $\mathrm{n}^{\circ}$ 5, Part K, pp. 177-208, Springer-Verlag, Berlin.

Cossa, D., Harmelin-Vivien, M., Mellon-Duval, C., Loizeau, V., Averty, B., Crochet, S., Chou, L., Cadiou, J.F., 2012. Influences of bioavailability, trophic position, and growth on Methylmercury in Hakes (Merluccius merluccius) from Northwestern Mediterranean and Northeastern Atlantic. Environmental Science \& Technology, 46, 4885-4893.

Cresson, P., Fabri, M.C., Bouchoucha, M., Brach Papa, C., Chavanon, F., Jadaud, A., Knoery, J., Miralles, F., Cossa, D., 2014. Mercury in organisms from the Northwestern Mediterranean slope: Importance of food sources. Science of the Total Environment, 497-498, 229-23,.

D’Onghia, G., Calculli, C., Capezzuto, F., Carlucci, R., Carluccio, A., Grehan, A., Indennidate, A., Maiorano, P., Mastrototaro, F., Pollice, A., Russo T., 2017. Anthropogenic impact in the Santa 
Maria di Leuca cold-water coral province (Mediterranean Sea): Observations and conservation straits. Deep Sea Research, Part II, Topical Studies in Oceanography, 145, 87101.

Dachs, J., Bayona, J.M., Fowler, S.W., Miquel, J.-C., Albaigés, J., 1996. Vertical fluxes of polycyclic aromatic hydrocarbons and organochlorine compounds in the western Alboran Sea (southwestern Mediterranean). Marine Chemistry, 52, 75-86.

Damiano, S., Papetti, P., Menesatti, P., 2011. Accumulation of heavy metals to assess the health status of swordfish in a comparative analysis of Mediterranean and Atlantic areas, Marine Pollution Bulletin 62, 1920-1925.

Danovaro, R., Pusceddu, A. 2007. Ecomanagement of biodiversity and ecosystem functioning in the Mediterranean Sea: concerns and strategies. Chemistry and Ecology, 23, 347-360.

Danovaro, R., Dinet, A., Duineveld, G., Tselepides, A., 1999. Benthic response to particulate fluxes in different trophic environments: a comparison between the Gulf of Lions-Catalan Sea (Western Mediterranean) and the Cretan Sea (Eastern-Mediterranean). Progress in Oceanography, 44, 287-312.

Danovaro, R., 2003. Pollution threats in the Mediterranean Sea: an overview. Chemistry and Ecology 19 (1), 15-32.

Danovaro, R., Gambi, C., Dell'Anno, A., Corinaldesi, C., Fraschetti, S., Vanreusel, A., Vincx, M. and Gooday, A.J., 2008. Exponential decline of deep-sea ecosystem functioning linked to benthic biodiversity loss. Current Biology, 18, 1-8.

Danovaro, R., Corinaldesi, C., D'Onghia, G., Galil, B., Gambi, C., Gooday, A.J., Lampadariou, N., Luna, G.M., Morigi, C., Olu, K., Polymenakou, P., 2010. Deep-sea biodiversity in the Mediterranean Sea: The known, the unknown, and the unknowable. PloS One, 5(8), p.e 11832.

Danovaro, R., Snelgrove, P.V.R., Tyler, P., 2014. Challenging the paradigms of deep-sea ecology. Trends in Ecology \& Evolution 29, 8, 465-475.

Danovaro, R., Corinaldesi, C., Rastelli, E., Dell'Anno, A., 2015. Towards a better quantitative assessment of the relevance of deep-sea viruses, Bacteria and Archaea in the functioning of the ocean seafloor. Aquat. Microb. Ecol. 75: 81-90. https://doi.org/10.3354/ame01747

Danovaro, R., Carugati, L., Boldrin, A., Calafat, A., Canals, M., Fabres, J., Finlay, K., Heussner, S., Miserocchi, S., Sanchez-Vidal, A., 2017. Deep-water zooplankton in the Mediterranean Sea: 
results from a continuous, synchronous sampling over different regions using sediment traps. Deep Sea Research, Part I, 103, 103-114.

Danovaro, R., Fanelli, E., Aguzzi, J., Billett, D., Carugati, L., Corinaldesi, C., Dell'Anno, A., Gjerde, K., Jamieson, A.J., Kark, S., McClain, C., Levin, L., Levin, N., Ramirez-Llodra, E., Ruhl, H., Smith, C.R., Snelgrove, P.V.R., Thomsen, L., Van Dover, C., Yasuhara, M., 2019. Ecological variables for developing a global deep-ocean monitoring and conservation strategy. Nature Ecol. Evol., in press.

Dauvin, J.C., 2010. Towards an impact assessment of bauxite red mud waste on the knowledge of the structure and functions of bathyal ecosystems: The example of the Cassidaigne canyon (north-western Mediterranean Sea), Marine Pollution Bulletin 60, 197-206.

de Vivero J.L.S., Rodriguez Mateos J C, 2015. Marine Governance in the Mediterranean Sea. In Gilek M., Kern K. (eds.), Governing Europe's Marine Environment: Europeanization of Regional Seas or Regionalization of EU policies? 2015. Published by Ashgate Publishing.

Dell'Anno, A., Mei, M.L., Pusceddu, A., Danovaro, R., 2002. Assessing the trophic state and eutrophication of coastal marine systems: a new approach based on the biochemical composition of sediment organic matter. Marine Pollution Bulletin 44, 611-622.

Denda, A., Christiansen, B., 2014. Zooplankton distribution patterns at two seamounts in the subtropical and tropical NE Atlantic. Marine ecology, 35(2), 159-179.

DeRuiter, S.L., Larbi Doukara, K., 2012. Loggerhead turtles dive in response to airgun sound exposure, Endangered Species Research 16, 55-63.

Desforges J.P.W., Galbraith M., Dangerfield N., Ross P.S., 2014. Widespread distribution of microplastics in subsurface seawater in the NE Pacific Ocean Marine Pollution Bulletin, 79: 94-99.

Doya, C., Aguzzi, J., Chatzievangelou, D., Costa, C., Company, J.B., Tunnicliffe, V., 2015. The seasonal use of small-scale space by benthic species in a transiently hypoxic area. Journal of Marine Systems, 154, 280-290.

Drazen, J.C., Haedrich, R.L., 2012. A continuum of life histories in deep-sea demersal fishes, DeepSea Research, Part I , 61, 34-42.

Durrieu de Madron, X., Houpert, L., Puig, P., Sanchez-Vidal, A., Testor, P., Bosse, A., Estournel, C., Somot, S., Bourrin, F., Bouin, M. N., Beauverger, M., Beguery, L., Calafat, A., Canals, M., Cassou, C., Coppola, L., Dausse, D., D'Ortenzio, F.; Font, J., Heussner, S., Kunesch, S., Lefevre, D., Le Goff, H., Martín, J., Mortier, L., Palanques, A., Raimbault, P., 2013. 
Interaction of dense shelf water cascading and open-sea convection in the northwestern Mediterranean during winter 2012. Geophysical Research Letters, American Geophysical Union, 2013, 40, 1379-1385. M. Baklouti, C. Bancon-Montigny, S. Belviso, N. Bensoussan, B. Bonsang, I. Bouloubassi, C. Brunet, J.-F. Cadiou, F. Carlotti, M. Chami, S. Charmasson, B. Charrière, J. Dachs, D. Doxaran, J.-C. Dutay, F. Elbaz-Poulichet, M. Eléaume, F. Eyrolles, C. Fernandez, S. Fowler, P. Francour, J.C. Gaertner, R. Galzin, S. Gasparini, J.-F. Ghiglione, J.-L. Gonzalez, C. Goyet, L. Guidi, K. Guizien, L.-E. Heimbürger, S.H.M. Jacquet, W.H. Jeffrey, F. Joux, P. Le Hir, K. Leblanc, D. Lefèvre, C. Lejeusne, R. Lemé, M.-D. Loÿe-Pilot, M. Mallet, L. Méjanelle, F. Mélin, C. Mellon, B. Mérigot, P.-L. Merle, C. Migon, W.L. Miller, L. Mortier, B. Mostajir, L. Mousseau, T. Moutin, J. Para, T. Pérez, A. Petrenko, J.-C. Poggiale, L. Prieur, M. Pujo-Pay, Pulido-Villena, P. Raimbault, A.P. Rees, C. Ridame, J.-F. Rontani, D. Ruiz Pino, M.A. Sicre, V. Taillandier, C. Tamburini, T. Tanaka, I. Taupier-Letage, M. Tedetti, P. Testor, H. Thébault, B. Thouvenin, F. Touratier, J. Tronczynski, C. Ulses, F. Van Wambeke, V. Vantrepotte, S. Vaz, R. Verney, 2011. Marine ecosystems' responses to climatic and anthropogenic forcings in the Mediterranean, Progress in Oceanography, 91, 97-166.

EC 2006. No 1881/2006 of 19 December 2006 setting maximum levels for certain contaminants in foodstuffs. Official Journal of the European Union, L364/5-24.

EC 2008. DIRECTIVE 2008/105/EC OF THE EUROPEAN PARLIAMENT AND OF THE COUNCIL of 16 December 2008 on environmental quality standards in the field of water policy, amending and subsequently repealing Council Directives 82/176/EEC, 83/513/EEC, 84/156/EEC, 84/491/EEC, 86/280/EEC and amending Directive 2000/60/EC of the European Parliament and of the Council. Official Journal of the European Union, L348/84-97.

EC 2017. COMMISSION DECISION (EU) 2017/848 of 17 May 2017 laying down criteria and methodological standards on good environmental status of marine waters and specifications and standardised methods for monitoring and assessment, and repealing Decision 2010/477/EU. Official Journal of the European Union, L125/43-74.

Edds-Walton, P.L., 1997. Acoustic communication signals of mysticete whales, Bioacoustics, 8, 4760. 
EEA, 1999. State and pressures of the marine and coastal Mediterranean environment.

\section{Environmental Issue series, No5, European Commission, 137 pp.}

Eigaard, O.R., Bastardie, F., Hintzen, N.T., Buhl-Mortensen, L., Buhl-Mortensen, P., Catarino, R., Dinesen, G.E., Egekvist, J., Fock, H.O., Geitner, K., Gerritsen, H.D., González, M.M., Jonsson, P., Kavadas, S., Laffargue, P., Lundy, M., Gonzalez-Mirelis, G., Nielsen, J.R., Papadopoulou, N., E. Posen, P.E., Pulcinella, J., Russo, T., Sala, A., Silva, C., Smith, C.J., Vanelslander, B., Rijnsdorp, A.D., 2017. The footprint of bottom trawling in European waters: distribution, intensity, and seabed integrity, Ices Journal of Marine Science 74, 847-865.

Elahi, R., Ferretti, F., Bastari, A., Cerrano, C., Colloca F., Kowalik, J., Ruckelshaus, M., Struck, A., Micheli, F., 2018. Leveraging vessel traffic data and a temporary fishing closure to inform marine management. Front. Ecol. Environ., 16(8), 1-7.

Emig, C.C., Geistdoerfer, P., 2004. The Mediterranean deep-sea fauna: historical evolution, bathymetric variations and geographical changes. Carnets de Geologie, Madrid, 4(A01), 10 p. doi: $10.4267 / 2042 / 3230$

Estournel, C., Zervakis, V., Marsaleix, P., Papadopoulos, A., Auclair, F., Perivoliotis, L., Tragou, E., 2005. Dense water formation and cascading in the Gulf of Thermaikos (North Aegean), from observations and modelling. Cont. Shelf Res. 25, 2366-2386.

Evans, J., Aguilar, R., Alvarez, H., Borg, J.A., Garcia, S., Knittweis, L., Schembri, P.J., 2016. Recent evidence that the deep sea around Malta is a biodiversity hotspot. 41st Congress of the Mediterranean Science Commission (CIESM), Kiel, Germany, 12 - 16 September 2016

Fabri, M.C., Bargain, A., Pairaud, I., Pedel, L., Taupier-Letage, I., 2017. Cold-water coral ecosystems in Cassidaigne Canyon: An assessment of their environmental living conditions, Deep Sea Research, Part II, 137, 436-453.

Fabri, M.C., Pedel, L., Beuck, L., Galgani, F., Hebbeln, D., Freiwald, A., 2014. Megafauna of vulnerable marine ecosystems in French Mediterranean submarine canyons: Spatial distribution and anthropogenic impacts, Deep Sea Research, Part I, 104, 184-207.

Fabri, M.C., Vinha, B., Allais, A.G., Bouhier, M.-E., Dugornay, O., Gaillot, A., \& Arnaubec, A. (under revision). Evaluating ecological status of cold-water coral habitats using non-invasive methods, an example from Cassidaigne canyon, northwestern Mediterranean Sea. Progress in Oceanography in press 
Cantafaro, A.-L., Fanelli, E., Carugati, L., Danovaro, R., 2018. Review of literature on the implementation of the MSFD to the deep Mediterranean Sea.IDEM project, Deliverable 1.1. 228 p. www.msfd-idem.eu. doi.org/10.13155/53809

Fanelli, E., Cartes, J.E., Rumolo, P., Sprovieri, M., 2009. Food-web structure and trophodynamics of mesopelagic-suprabenthic bathyal macrofauna of the Algerian Basin based on stable isotopes of carbon and nitrogen, Deep Sea Research, Part I, 56, 1504-1520.

Fanelli, E., Badalamenti, F., D’Anna, G., Pipitone, P., Romano C., 2010. Trophodynamic effects of trawling on the feeding ecology of Pandora, Pagellus erythrinus off the northern Sicily coast (Mediterranean Sea). Marine and Freshwater Research 61, 408-417.

Fanelli, E., Papiol, V., Cartes, J.E., Rumolo, P., Brunet, C., Sprovieri, M., 2011a. Food web structure of the megabenthic, invertebrate epifauna on the Catalan slope (NW Mediterranean): evidence from $\delta^{13} \mathrm{C}$ and $\delta^{15} \mathrm{~N}$ analysis. Deep Sea Research, Part I, 58, 98-109.

Fanelli, E., Cartes, J.E., Papiol, V., 2011b. Food web structure of deep-sea macrozooplankton and micronekton off the Catalan slope: Insight from stable isotopes, Journal of Marine Systems, 87, 79-89.

Fanelli, E., Cartes, J.E. Papiol, V., 2012. Assemblage structure and trophic ecology of deep-sea demersal cephalopods in the Balearic basin (NW Mediterranean). Marine and Freshwater Research, 63, 264-274.

Fanelli, E., Cartes, J. E., Papiol, V., López-Pérez, C., 2013. Environmental drivers of megafaunal assemblage composition and biomass distribution over mainland and insular slopes of the Balearic Basin (Western Mediterranean). Deep Sea Research, Part I, 78, 79-94.

Fanelli, E., Papiol, V., Cartes, J.E., Rodriguez-Romeu, O., 2014. Trophic ecology of Lampanyctus crocodilus on north-west Mediterranean Sea slopes in relation to reproductive cycle and environmental variables, Journal of Fish Biology 84, 1654-1688. 
Fanelli, E., Delbono, I., Ivaldi, R., Pratellesi, M., Cocito, S., Peirano, A., 2017. Cold water coral Madrepora oculata in the eastern Ligurian Sea (NW Mediterranean): historical banks and

Fanelli E., Bianchelli S., Danovaro R., 2018. Deep-sea mobile megafauna of Mediterranean submarine canyons and open slopes: analysis of spatial and bathymetric gradients. Progress in Oceanography, 168, 23-24.

FAO, 2009. International Guidelines for the Management of Deep-sea Fisheries in the High Seas. FAO, Rome, Italy, 73pp.

FAO, 2016. Report of the FAO Workshop on Deep-sea Fisheries and Vulnerable Marine Ecosystems of the Mediterranean, Rome, Italy, 18-20 July 2016. FAO Fisheries and Aquaculture Report No. 1183, Rome, Italy.

FAO, 2018. The State of Mediterranean and Black Sea Fisheries. General Fisheries Commission for the Mediterranean. Rome, 172pp

Favali, P., Chierici, F., Marinaro, G., Giovanetti, G., Azzarone, A., Beranzoli, L., and KMNET consortium, 2013. NEMO-SN1 abyssal cabled observatory in the Western Ionian Sea. IEEE Journal of Oceanic Engineering, 38, 358-374.

Fernandez-Arcaya, U., Ramirez-Llodra E., Aguzzi J., Allcock A.L., Davies J.S., Dissanayake A., Harris P., Howell K., Huvenne, V.A.I., Ismail K., Macmillan-Lawler M., Martín J., Menot L., Nizinski M., Puig P., Rowden A., Sanchez F., Steward H.A., Van den Beld I. 2017. Ecological role of submarine canyons and need for canyon conservation: a review. Front. Mar. Sci. 31.

Ferreira J.G., Andersen J.H., Borja A., Bricker S.B., Camp J., Cardoso da Silva M., Garcés E., Heiskanen A.S., Humborg C., Ignatiades L., Lancelot C., Menesguen A., Tett P., Hoepffner N., Claussen U., 2011. Overview of eutrophication indicators to assess environmental status within the European Marine Strategy Framework Directive. Estuarine, Coastal and Shelf Science, 93, 117-131.

Ferreira, J.G., Andersen, J.H., Borja, A., Bricker, S.B., Camp, J., Cardoso da Silva, M., Garcés, E., Heiskanen, A.S., Humborg, C., Ignatiades, L., Lancelot, C., Menesguen, A., Tett, P., Hoepffner, N., Claussen, U., 2010. Marine Strategy Framework Directive Task Group 5 Report Eutrophication. EUR 24338

Ferreira, J.G., Vale, C., Soares, C.V., Salas, F., Stacey, P.E., Bricker, S.B., Silva, M.C., Marques, J.C., 2007. Monitoring of coastal and transitional waters under the EU water framework directive, Environmental Monitoring and Assessment, 135, 195-216. 
Fichaut, M., Garcia, M.J., Giorgetti, A., Iona, A., Kuznetsov, A., Rixen, M., Group, M., 2003. MEDAR/MEDATLAS 2002: A Mediterranean and Black Sea database for operational oceanography. In: Dahlin, H., Flemming, N.C., Nittis, K., Petersson, S.E. (eds.), Elsevier Oceanography Series, $\mathrm{n}^{\circ}$ 69, pp. 645-648, Elsevier, doi: https://doi.org/10.1016/S04229894(03)80107-1. 0422-9894

Fliedner, A., Rüdel, H., Knopf, B., Lohmann, N., Paulus, M., Jud, M., Pirntke, U., Koschorreck, J. (2018). Assessment of seafood contamination under the marine strategy framework directive: contributions of the German environmental specimen bank. Environmental Science and Pollution Research, 25(27), 26939-26956.

Fontanier, C., Fabri, M.C., Buscail, R., Biscara, L., Koho, K., Reichart, G.J., Cossa, D., Galaup, S., Chabaud, G., Pigot, L. (2012) Deep-sea foraminifera from the Cassidaigne Canyon (NW Mediterranean): Assessing the environmental impact of bauxite red mud disposal. Marine Pollution Bulletin, 64, 1895-1910.doi : 10.1016/j.marpolbul.2012.06.016

Fontanier, C., Biscara, L., Mamo, B., Delord, E., 2014. Deep-sea benthic foraminifera in an area around the Cassidaigne Canyon (NW Mediterranean) affected by bauxite discharges, Marine Biodiversity 44, 4, doi: 10.1007/s12526-014-0281-9.

Foote, A.D., Osborne, R.W., Hoelzel, A.R., 2004. Environment - Whale-call response to masking boat noise, Nature 428, 6986, 910-910, doi: 10.1038/428910a.

Freiwald, A., Beuck, L., Rüggeberg, A., Taviani, M., Hebbeln, D., R/V Meteor M70-1 Participants, 2009. The white coral community in the central Mediterranean Sea revealed by ROV surveys. Oceanography, 22(1), 58-74.

Galgani, F., Leaute, J.P., Moguedet, P., Souplet, A., Verin, Y., Carpentier, A., Goraguer, H., Latrouite, D., Andral, B., Cadiou, Y., Mahe, J.C., Poulard, J.C., Nerisson, P., 2000. Litter on the sea floor along European coasts. Marine Pollution Bulletin 40 (6), 516-527.

Galil, B. S. (2004). The limit of the sea: the bathyal fauna of the Levantine Sea. Scientia Marina, 68(S3), 63-72.

Galil, B.S., 2007. Loss or gain? Invasive aliens and biodiversity in the Mediterranean Sea, Marine Pollution Bulletin 55, 7-9, 314-322, doi: 10.1016/j.marpolbul.2006.11.008.

Galil, B.S., Danovaro, R., Rothman, S.B.S., Gevili, R. and Goren, M., 2019. Invasive biota in the deep-sea Mediterranean: an emerging issue in marine conservation and management. Biological invasions, 21(2), 281-288.

Galil, B., and Herut, B. (2011). Marine environmental issues of deep-sea oil and gas exploration 
and exploitation activities off the coast of Israel. IOLR Report H15/2011, 24 p.

Galil, B.S., Golik, A., Türkay, M., 1995. Litter at the bottom of the sea: A sea bed survey in the Eastern Mediterranean, Marine Pollution Bulletin 30, 1, 22-24, doi: https://doi.org/10.1016/0025-326X(94)00103-G.

Galil, B.S., Marchini, A., Occhipinti-Ambrogi, A., 2016. East is east and West is west? Management of marine bioinvasions in the Mediterranean Sea, Estuarine, Coastal and Shelf Science, doi: http://dx.doi.org/10.1016/j.ecss.2015.12.021

Galil, B.S., Marchini, A., Occhipinti-Ambrogi, A., Minchin, D., Narscius, A., Ojaveer, H., Olenin, S., 2014. International arrivals: widespread bioinvasions in European Seas, Ethology Ecology \& Evolution 26, 2-3, 152-171, doi: 10.1080/03949370.2014.897651.

Galil, B., Marchini, A., Occhipinti-Ambrogi, A., Ojaveer, H., 2017. The enlargement of the Suez Canal - Erythraean introductions and management challenges, Management of Biological Invasions 8, 2, 141-152, doi: 10.3391/mbi.2017.8.2.02.

Galil, B.S., Danovaro, R., Rothman, S.B.S., Gevili, R., Goren, M., 2018. Invasive biota in the deep-sea Mediterranean: an emerging issue in marine conservation and management. Biological Invasions, 21(2): 281-288

Gambi, C., Pusceddu, A., Benedetti-Cecchi, L., \& Danovaro, R. (2014). Species richness, species turnover and functional diversity in nematodes of the deep $M$ editerranean $S$ ea: searching for drivers at different spatial scales. Global ecology and biogeography, 23(1), 24-39.

Gascuel, D., Coll, M., Fox, C., Guénette, S., Guitton, J., Kenny, A., Knittweis, L., Nielsen, J. R., Piet, G. , Raid, T. , Travers-Trolet, M., and Shephard, S., 2016. Fishing impact and environmental status in European seas: a diagnosis from stock assessments and ecosystem indicators, Fish and Fisheries, 17, 31-55.

GFCM, 2017. Report of the first meeting of the Working Group on Vulnerable Marine Ecosystems (WGVME). Malaga, Spain, 3-5 April 2017

Giusti, M., Innocenti, C., \& Canese, S. (2014). Predicting suitable habitat for the gold coral Savalia savaglia (Bertoloni, 1819) (Cnidaria, Zoantharia) in the South Tyrrhenian Sea. Continental Shelf Research, 81, 19-28.10.1016/j.csr.2014.03.011

Giusti, M., Bo, M., Angiolillo, M., Cannas, R., Cau, A., Follesa, M.C., Canese, S. (2017). Habitat preference of Viminella flagellum (Alcyonacea: Ellisellidae) in relation to bathymetric variables in southeastern Sardinian waters. Continental Shelf Research, 138, 4150.10.1016/j.csr.2017.03.004 
Goren, M., Galil, B.S., Diamant, A., Stern, N., Levitt-Barmats, Y., 2016. Invading up the food web? Invasive fish in the southeastern Mediterranean Sea, Marine Biology, 163, 8, doi: 10.1007/s00227-016-2950-7.

Gregory, M., 2009. Environmental implications of plastic debris in marine settings entanglement, ingestion, smothering, hangers-on, hitch-hiking and alien invasions. Philos Trans R Soc Lond B Biol Sci., 364 (1526), 2013-2025.

Gress, E., Andradi-Brown, D.A., Woodall, L., Schofield, P.J., Stanley, K., Rogers, A.D., 2017. Lionfish (Pterois spp.) invade the upper-bathyal zone in the western Atlantic, Peerj 5, doi: 10.7717/peerj.3683.

Guerzoni, S., Chester, R., Dulac, F., Herut, B., Loye-Pilot, M.D., Measures, C., Migon, C., Molinaroli, E., Moulin, C., Rossini, P., Saydam, C., Soudine, A., Ziveri, P., 1999. The role of atmospheric deposition in the biogeochemistry of the Mediterranean Sea, Progress in Oceanography 44, 1-3, 147-190.

Keeling, R.F., Kortzinger, A., Gruber, N., 2010. Ocean Deoxygenation in a Warming World, Annual Review of Marine Science 2, 199-229, doi: 10.1146/annurev.marine.010908.163855.

Halpern BS, Walbridge S, Selkoe KA, Kappel CV, Micheli F, D'Agrosa C, Bruno JF, Casey KS, Ebert C, Fox HE, Fujita R, Heinemann D, Lenihan HS, Madin EMP, Perry MT, Selig ER, Spalding M, Steneck R, Watson R (2008). A global map of human impact on marine ecosystems, Science $319,5865,948-952$.

Harmelin-Vivien M., Bodiguel X., Charmasson S., Loizeau V., Mellon-Duval C., Tronczynski J., Cossa D., 2012. Differential biomagnification of PCB, PBDE, $\mathrm{Hg}$ and Radiocesium in the food web of the European hake from the NW Mediterranean, Marine Pollution Bulletin 64, 5, 974-983.

Harmon, S.M., 2015. The Toxicity of Persistent Organic Pollutants to Aquatic Organisms, in "Persistent Organic Pollutants (POPs): Analytical Techniques, Environmental Fate and Biological Effects" by Eddy Y. Zeng (Editor), Comprehensive Analytical Chemistry, 67, 587613.

Herut, B., Galil, B., Shefer, E., 2010. Monitoring Alpha - disposal site of dredged material in the Mediterranean Sea. Results of monitoring July-September 2009. Israel Oceanographic \& Limnological Research Reports (in Hebrew) 9, 47

Heussner, S., Durrieu de Madron, X., Calafat, A., Canals, M., Carbonne, J., Delsaut, N., Saragoni, G., 2006. Spatial and temporal variability of downward particle fluxes on a continental slope: 
Lessons from an 8-yr experiment in the Gulf of Lions (NW Mediterranean), Marine Geology, 234, 63-92.

Hildebrand, J.A., 2009. Anthropogenic and natural sources of ambient noise in the ocean, Marine Ecology Progress Series, 395, 5-20, doi: 10.3354/meps08353.

Holler, P., Markert, E., Bartholoma, A., Capperucci, R., Hass, H.C., Kroncke, I., Mielck, F., Reimers, H.C., 2017. Tools to evaluate seafloor integrity: comparison of multi-device acoustic seafloor classifications for benthic macrofauna-driven patterns in the German Bight, southern North Sea. Geo-Marine Letters, 37, 93-109.

ICES. 2015. Report of the workshop on guidance for the review of MSFD decision descriptor 3 commercial fish and shellfish II (WKGMSFDD3-II), 10-12 February 2015, ICES Headquarters, Denmark. ICES CM 2015/ACOM:48, 36 pp.

ICES. 2016. EU request to provide guidance on operational methods for the evaluation of the MSFD Criterion D3C3. In Report of the ICES Advisory Committee, 2016. ICES Advice 2016, Book 1, Section 1.6.2.2.

ICES, 2017. Report of the Workshop on Guidance on Development of Operational Methods for the Evaluation of the MSFD Criterion D3.3 (WKIND3.3ii), 1-4 November 2016, Copenhagen, Denmark. ICES CM 2016/ACOM:44. 145 pp.

Iken, K., Brey, T., Wand, U., Voigt, J., Junghans, P., 2001. Food web structure of the benthic community at the Porcupine Abyssal Plain (NE Atlantic): a stable isotope analysis. Progress in Oceanography, 50(1-4), 383-405.

Innocenti, G, Stasolla, G., Goren, M., Stern, N., Levitt-Barmats, Y., Diamant, A., Galil, B.S., 2017. Going down together: invasive host, Charybdis longicollis (Leene, 1938) (Decapoda: Brachyura: Portunidae) and invasive parasite, Heterosaccus dollfusi Boschma, 1960 (Cirripedia: Rhizocephala: Sacculinidae) on the upper slope off the Mediterranean coast of Israel. Marine Biology Research, 13, 229-236.

loakeimidis, C., Zeri, C., Kaberi, E, Galatchi, M., Antoniadis, K., Streftaris, N., Galgani, F. Papathanassiou, E., Papatheodorou, G., 2014. A comparative study of marine litter on the seafloor of coastal areas in the Eastern Mediterranean and Black Seas. Marine Pollution Bulletin, 89, 296-30.

Iwata, H, Tanabe, S, Sakai, N, Nishimura, A, Tatsukawa, R., 1994. Geographical distribution of persistent organochlorines in air, water and sediments from Asia and Oceania, and their 
implications for global redistribution from lower latitudes. Environmental Pollution 85, 1533.

Jimenez, C., Patsalou, P., Andreou, V., Huseyinoglu, M.F., Çiçek, B.A., Hadjioannou, L., Petrou, A., 2019. Out of sight, out of reach, out of mind: invasive lionfish Pterois miles in Cyprus at depths beyond recreational diving limits. 1st Mediterranean Symposium on the NonIndigenous Species (Antalya, Turkey, 17-18 January 2019). pp. 59-64.

Junque, E., Gari, M., Arce, A., Torrent, M., Sunyer, J., Grimalt, J.O., 2017. Integrated assessment of infant exposure to persistent organic pollutants and mercury via dietary intake in a central western Mediterranean site (Menorca Island), Environmental Research 156, 714-724.

Junqué, E., Garí M., Llull R.M., Grimalt J.O., 2018. Drivers of the accumulation of mercury and organochlorine pollutants in Mediterranean lean fish and dietary significance. Science of the total Environment 634, 170-180.

Katsanevakis, S., Verriopoulos, G., Nicolaidou, A., Thessalou-Legaki, M., 2007. Effect of marine litter on the benthic megafauna of coastal soft bottoms: A manipulative field experiment. Marine Pollution Bulletin, 54, 771-778.

Kenny, A.J., Cato, I., Desprez, M., Fader, G., Schuttenhelm, R.T.E., Side, J., 2003. An overview of seabed-mapping technologies in the context of marine habitat classification, Ices Journal of Marine Science 60, 2, 411-418.

Klein, B., Roether, W., Kress, N., Manca, B.B., d'Alcala, M.R., Souvermezoglou, E., Theocharis, A., Civitarese, G., Luchetta, A., 2003. Accelerated oxygen consumption in eastern Mediterranean deep waters following the recent changes in thermohaline circulation, Journal of Geophysical Research-Oceans 108, C9, doi: 10.1029/2002jc001454.

Klein, B., Roether, W., Manca, B.B., Bregant, D., Beitzel, V., Kovacevic, V., Luchetta, A., 1999. The large deep water transient in the Eastern Mediterranean, Deep Sea Research, Part I, 46, 371414.

Koenig, S., Fernandez, P., Sole, M., 2012. Differences in cytochrome P450 enzyme activities between fish and crustacea: Relationship with the bioaccumulation patterns of polychlorobiphenyls (PCBs). Aquatic Toxicology, 108, 11-17.

Koenig, S., Fernandez, P., Company, J.B., Huertas, D., Sole, M., 2013a. Are deep-sea organisms dwelling within a submarine canyon more at risk from anthropogenic contamination than those from the adjacent open slope? A case study of Blanes canyon (NW Mediterranean), Progress in Oceanography, 118, 249-259. 
Koenig, S., Huertas, D., Fernández, P., 2013b. Legacy and emergent persistent organic pollutants (POPs) in NW Mediterranean deep-sea organisms, Science of the Total Environment, 443, 358-366.

Koenig, S., Sole, M., Fernandez-Gomez, C., Diez, S., 2013c. New insights into mercury bioaccumulation in deep-sea organisms from the NW Mediterranean and their human health implications, Science of the Total Environment, 442, 329-335.

Koppelmann, R., Bottger-Schnack, R., Mobius, J., Weikert, H., 2009. Trophic relationships of zooplankton in the eastern Mediterranean based on stable isotope measurements, Journal of Plankton Research, 31, 669-686.

Koslow, J.A., Boehlert, G.W., Gordon, J.D.M., Haedrich, R.L., Lorance, P., Parin, N., 2000. Continental slope and deep-sea fisheries: implications for a fragile ecosystem. ICES Journal of Marine Science, 57, 548-557.

Kress, N., Hornung, H., Herut, B., 1998. Concentrations of $\mathrm{Hg}, \mathrm{Cd}, \mathrm{Cu}, \mathrm{Zn}, \mathrm{Fe}$ and $\mathrm{Mn}$ in deep sea benthic fauna from the southeastern Mediterranean Sea: A comparison study between fauna collected at a pristine area and at two waste disposal sites. Marine Pollution Bullettin, 36, 911-921.

Kress, N., Fainshtein, G., Hornung, H., 1996. Monitoring of $\mathrm{Hg}, \mathrm{Cd}, \mathrm{Cu}, \mathrm{Pb}, \mathrm{Zn}, \mathrm{Co}, \mathrm{Be}$ and $\mathrm{V}$ at a deep water coal fly ash dumping site. MAP Technical Reports Series $N^{\circ} 104$, UNEP/FAO

Kress, N., Gertman, I., Herut, B., 2014. Temporal evolution of physical and chemical characteristics of the water column in the Easternmost Levantine basin (Eastern Mediterranean Sea) from 2002 to 2010, Journal of Marine Systems 135, 6-13, doi: 10.1016/j.jmarsys.2013.11.016.

Lawrence, M.J., Stemberger, H.I.J., Zolderdo, A.J., Struthers, D.P., Cooke S.J., 2015. The effects of modern war and military activities on biodiversity and the environment. Environmental Reviews 23(4), 443-460

Lastras, G., Canals, M., Ballesteros, E., Gili, J.M., Sanchez-Vidal, A., 2016. Cold-water corals and anthropogenic impacts in La Fonera submarine canyon head. PLoS One, 16;11(5):e0155729.

Lauria, V., Garofalo, G., Fiorentino, F., Massi, D., Milisenda, G., Piraino, S., Russo, T., Gristina, M., 2017. Species distribution models of two critically endangered deep-sea octocorals reveal fishing impacts on vulnerable marine ecosystems in central Mediterranean Sea. Scientific Reports, 7, 8049. 
Le Corre, G., Farrugio, H., 2011. Note sur la création par la CGPM d'une Zone de pêche réglementée dans le golfe du Lion en mars 2009. RBE/HMT 2011-002. https://archimer.ifremer.fr/doc/00086/19688/

Lejeusne, C., Chevaldonné, P., Pergent-Martini, C., Boudouresque, C., Pérez, T., 2010. Climate change effects on a miniature ocean: the highly diverse, highly impacted Mediterranean Sea. Trends in Ecology \& Evolution 1204: published online. doi 10.1016/j.tree.2009.1010.1009.

Levin, L.A., 2003. Oxygen minimum zone benthos: Adaptation and community response to hypoxia. Oceanography and Marine Biology: an Annual Review 2003, 41, 1-45.

Levitus, S., Antonov, J.I., Boyer, T.P., Stephens, C., 2000. Warming of the World Ocean. Science, 287, 2225-2229

Lipiatou, E., Marty, J.C., Saliot, A., 1993. Sediment trap fluxes of polycyclic aromatic hydrocarbons in the Mediterranean Sea. Marine Chemistry, 44, 43-54.

Livnat, M., 2014. Offshore safety in the Eastern Mediterranean energy sector. Implications of the new EU directive. Mediterranean Paper Series 2014, The German Marshall Fund of the United States, Washington DC, USA, 12 p.

Llull, R.M., Garí, M., Canals, M., Rey-Maquieira, T., Grimalt, J.O., 2017.Mercury concentrations in lean fish from the Western Mediterranean Sea: Dietary exposure and risk assessment in the population of the Balearic Islands. Environmental Research, 158, 16-23.

Lo lacono, C., Gràcia, E., Bartolomé, R., Coiras, E., Dañobeitia, J.J., Acosta, J., 2012. The habitats of the Chella Bank, Eastern Alboran Sea (Western Mediterranean). In: Harris P, Baker E (eds.) Seafloor geomorphology as benthic habitat: GeoHab Atlas of seafloor geomorphic features and benthic habitats. Elsevier, London, pp 681-687.

Lo Iacono, C., Robert, K., Gonzalez-Villanueva, R., Gori, A., Gili, J.-M., Orejas, C., 2018. Predicting cold-water coral distribution in the Cap de Creus Canyon (NW Mediterranean): implications for marine conservation planning. Progress in Oceanography, 169, 169-180.

Longhurst, A.R., 2017. Chapter 1 - Toward an ecological geography of the sea. In Ecological Geography of the Sea (Second Edition), Editor A.R. Longhurst, Academic Press, 1-17.

Luna, G.M., Bianchelli, S., Decembrini, F., De Domenico, E., Danovaro, R., Dell'Anno, A., 2012. The dark portion of the Mediterranean Sea is a bioreactor of organic matter cycling. Global Biogeochemical Cycles, 26(2) GB2017,doi:10.1029/2011GB004168 
Maglio, A., Pavan, G., Castellote, M., Frey, S., 2016. Overview of the noise hotspots in the ACCOBAMS area - Part I, Mediterranean Sea. Agreement on the Conservation of Cetaceans in the Black Sea, Mediterranean Sea and Contiguous Area, 44 p.

Martin, J., Palanques, A., Puig, P., 2006. Composition and variability of downward particulate matter fluxes in the Palamos submarine canyon (NW Mediterranean), Journal of Marine Systems, 60, 75-97.

Martin, J., Puig, P., Palanques, A., Masque, P., Garcia-Orellana, J., 2008. Effect of commercial trawling on the deep sedimentation in a Mediterranean submarine canyon, Marine Geology, 252, 150-155.

Martin, J., Miquel, J.C., Khripounoff, A., 2010. Impact of open sea deep convection on sediment remobilization in the western Mediterranean, Geophysical Research Letters, 37, doi: 10.1029/2010gl043704.

Martin, J., Puig, P., Masque, P., Palanques, A., Sanchez-Gomez, A., 2014. Impact of bottom trawling on deep-sea sediment properties along the flanks of a submarine canyon, Plos One 9, 8, doi: e104536, 10.1371/journal.pone.0104536.

Mascle, J., Mary, F., Praeg, D., Brosolo, L., Camera, L., Ceramicola, S., Dupré, S., 2014. Distribution and geological control of mud volcanoes and other fluid/free gas seepage features in the Mediterranean Sea and nearby Gulf of Cadiz, Geo-Marine Letters, 34, 89-110.

Massutí, E., Gordon, J. D., Moranta, J., Swan, S. C., Stefanescu, C., 2004. Mediterranean and Atlantic deep-sea fish assemblages: differences in biomass composition and size-related structure. Scientia Marina, 68 (S3), 101-115.

McCauley, R., Day, R.D., Swadling, K.M., Fitzgibbon, Q.P., Watson, R.A., 2017. Widely used marine seismic survey air gun operations negatively impact zooplankton, Nature Ecology \& Evolution, 1, 1-8, doi: 10.1038/s41559-017-0195.

Mecho A., Aguzzi J., De Mol B., Lastras G., Ramirez-Ilodra E., Bahamon N., Company J.B., Canals M. 2017. Visual faunistic exploration of geomorphological human-impacted deep-sea areas of the north-western Mediterranean Sea. J. Mar. Biol. Ass. UK, 98: 1241-1252.

MEDIAS Handbook, 2015. Common protocol for the Pan-MEditerranean Acoustic Survey (MEDIAS). Sète, France, March 2015, 21 pp. Available from: http://www.mediasproject.eu/medias/website/handbooks-menu/func-startdown/60/

MEDITS Handbook. Version n. 9, 2017, MEDITS Working Group: 106 pp. Available from: http://www.sibm.it/MEDITS\%202011/principaledownload.htm 
Mercado J.M., Yebra L., Cortés D., Beken C., Simboura M., Moncheva S., Alonso A., Gómez F., Salles S., Sánchez A., Valcarcel N., 2015. Designing joint monitoring programs for the MSFD Eutrophication assessment based on the monitoring strategy of UNEP/MAP (Barcelona Convention). In: Plans for the design of Joint Monitoring Programs in the Mediterranean and Black Sea regions adapted to MSFD requirements. - IRIS-SES project. Fransisco Alemany, Pagou Kalliopi, Giannoudi Louisa, Streftaris Nikos (eds.), IRIS-SES Project, May 2015.

Migeon, S., Mascle, J., Coste, M., Rouillard, P., 2012. Mediterranean submarine canyons and channels: Morphological and geological backgrounds. In: Wurtz, M. (ed.) Mediterranean submarine canyons: Ecology and Governance, pp. 27-41, IUCN, Gland, Switzerland and Malaga, Spain.

Moccia, D., Cau, A., Alvito, A., Canese, S., Cannas, R., Bo, M., Angiolillo, M., Follesa, M.C., 2019. New sites expanding the "Sardinian cold-water coral province" extension: A new potential cold-water coral network? Aquatic Conservation: Marine and Freshwater Ecosystems, 29, 153-160.

Molari M., Manini E., Dell'Anno A., 2013. Dark inorganic carbon fixation sustains the functioning of benthic deep-sea ecosystems. Global Biogeochemical Cycles, 27, 212-221.

Monaco, A., Peruzzi, S., 2002. The Mediterranean Targeted Project MATER-a multiscale approach of the variability of a marine system-overview. Journal of Marine Systems, 33, 3-21.

Montgomery, J. C., Radford, C. A. (2017). Marine bioacoustics. Current Biology, 27, R502-R507.

Morley, N.H., Burton, J.D., Tankere, S.P.C., Martin, J.M., 1997. Distribution and behaviour of some dissolved trace metals in the western Mediterranean Sea. Deep-Sea Research Part II, 44, 3-4, 675-691.

Murray, F., Cowie, P., 2011. Plastic contamination in the decapod crustacean Nephrops norvegicus (Linnaeus, 1758). Marine Pollution Bulletin, 62, 1207-1217.

Naumann, M.S., Imma Tolosa, I., Taviani, M., Grover, R., Christine Ferrier-Pagés, C., 2015. Trophic ecology of two cold-water coral species from the Mediterranean Sea revealed by lipid biomarkers and compound-specific isotope analyses. Coral Reefs, 34, 1165-1175. doi10.1007/s00338-015-1325-8.

NRC-National Research Council (US), 2003. Committee on Potential Impacts of Ambient Noise in the Ocean on Marine Mammals. Washington (DC): National Academies Press (US). 
Newman, S., Watkins, E., Farmer, A., Ten Brink, P., \& Schweitzer, J. P., 2015. The Economics of marine litter. In: Bergmann M., Gutow L., Klages M. (eds) Marine Anthropogenic Litter. Springer, Cham.

Nixon, S.W., 2009. Eutrophication and the macroscope. In Eutrophication in Coastal Ecosystems (pp. 5-19). Springer, Dordrecht.

Nowacek, D.P., Clark, C.W., Mann, D., Miller, P.J., Rosenbaum, H.C., Golden, J.S., Jasny, M., Kraska, J. and Southall, B.L., 2015, Marine seismic surveys and ocean noise: time for coordinated and prudent planning. Frontiers in Ecology and the Environment, 13, 378-386.

Oehlmann, J., Schulte-Oehlmann, U., Kloas, W., Jagnytsch, O., Lutz, I., Kusk, K., Wollenberger, L., Santos, E., Paull, G., Van Look, K., Tyler, C., 2009. A critical analysis of the biological impacts of plasticizers on wildlife. Philolosophical Transaction of the Royal Society Part B, 364, 20472062.

Olu-Le Roy, K., Sibuet, M., Fiala-Médioni, A., Gofas, S., Salas, C., Mariotti, A., Foucher, J.P., Woodside, J., 2004. Cold seep communities in the deep eastern Mediterranean Sea: composition, symbiosis and spatial distribution on mud volcanoes. Deep Sea Research Part I $51,1915-1936$.

Özcan, T., Ateş, A.S., Katağan, T., 2008. Expanding distribution and occurrence of the Indo-Pacific Stomatopod, Erugosquilla massavensis (Kossmann, 1880) on the Aegean coast of Turkey. Mediterranean Marine Science, 9(2), 115-118.

Özgür Özbek, E., Cardak, M., Kebapçioğlu, T., 2017. Spatio-temporal patterns of abundance, biomass and length of the silver-cheeked toadfish Lagocephalus sceleratus in the Gulf of Antalya, Turkish Journal of Fisheries and Aquatic Science, 17, 725-733.

Palanques, A., de Madron, X.D., Puig, P., Fabres, J., Guillen, J., Calafat, A., Canals, M., Heussner, S., Bonnin, J., 2006. Suspended sediment fluxes and transport processes in the Gulf of Lions submarine canyons. The role of storms and dense water cascading. Marine Geology, 234, 4361.

Palanques, A., Guillen, J., Puig, P., Durrieu de Madron, X., 2008. Storm-driven shelf-to-canyon suspended sediment transport at the southwestern Gulf of Lions. Continental Shelf Research, 28, 1947-1956.

Papiol, V., Cartes, J.E., Fanelli, E., Rumolo, P., 2013. Food web structure and seasonality of slope megafauna in the NW Mediterranean elucidated by stable isotopes: Relationship with available food sources, Journal of Sea Research, 77, 53-69. 
Parravicini, V., Azzurro, E., Kulbicki, M., \& Belmaker, J., 2015. Niche shift can impair the ability to predict invasion risk in the marine realm: an illustration using Mediterranean fish invaders. Ecology Letters, 18, 246-253.

Peng, C., Zhao, X.G., Liu, G.X., 2015. Noise in the sea and its impacts on marine organisms, International Journal of Environmental Research and Public Health, 12, 12304-12323.

Pham, C., Ramirez-Llodra, E., Claudia, H.S., Amaro, T., Bergmann, M., Canals, M., Company, J., Davies, J., Duineveld, G., Galgani, F., Howell, K., Huvenne, V.A., Isidro, E., Jones, D., Lastras, G., Morato, T., Gomes-Pereira, J., Purser, A., Stewart, H., Tojeira, I., Tubau, X., Van Rooij, D., Tyler, P., 2014. Marine litter distribution and density in European seas, from the shelves to deep basins. PLoS One, 9(4), e95839.

Piante, C., Ody, D., 2015. Blue Growth in the Mediterranean Sea: The Challenge of Good Environmental Status. MedTrends Project. WWF-France, 192 p.

Pierdomenico, M., Casalbore, D., Chiocci, F.L., 2019. Massive benthic litter funnelled to deep sea by flash-flood generated hyperpycnal flows. Scientific Reports 9: 5330.

Pinsky, M.L., Palumbi, S.R., 2014. Meta-analysis reveals lower genetic diversity in overfished populations. Molecular Ecology, 23(1), 29-39.

Piroddi, C., Coll, M., Liquete, C., Macias, D., Greer, K., Buszowski, J., Steenbeek, J., Danovaro, R. , Christensen, V., 2017. Historical changes of the Mediterranean Sea ecosystem: modelling the role and impact of primary productivity and fisheries changes over time. Scientific Reports, 7, 44491; doi: 10.1038/srep44491.

Popper, A.N., Hawkins, A.D., Fay, R.R., Mann, D.A., Bartol, S., Carlson, T.J., Coombs, S., Ellison, W.T., Gentry, R.L., Halvorsen, M.B., Lokkeborg, S., Rogers, P., Southall, B.L., Zeddies, D.G., Tavolga, W.N., 2014. Sound Exposure Guidelines for Fishes and Sea Turtles: A Technical Report prepared by ANSI-Accredited Standards Committee S3/SC1 and registered with ANSI. Springer Briefs in Oceanography. http://www.springer.com/gp/book/9783319066585

Porte, C., Escartin, E., Garcia, L.M., Solé, M., Albaigés, J., 2000. Xenobiotic metabolising enzymes and antioxidant defences in deep-sea fish: relationship with contaminant body burden. Marine Ecology Progress Series, 192, 259-266.

Poulos, S.E., Collins, M.B., Pattiaratchi, C., Cramp, A., Gull, W., Tsimplis, M., Papatheodorou, G., 1996. Oceanography and sedimentation in the semi-enclosed, deep-water Gulf of Corinth (Greece), Marine Geology, 134, 213-235. 
Puig, P., Canals, M., Company, J.B., Martin, J., Amblas, D., Lastras, G., Palanques, A., Calafat, A.M., 2012. Ploughing the deep sea floor, Nature 489, 7415, 286-289, doi: 10.1038/nature11410.

Pusceddu, A., Bianchelli, S., Martín, J., Puig, P., Palanques, A., Masqué, P., Danovaro, R., 2014. Chronic and intensive bottom trawling impairs deep-sea biodiversity and ecosystem functioning. Proceedings of the National Academy of Sciences, 111, 8861-8866.

Pusceddu, A., Bianchelli S., Gambi, C., Danovaro, R., 2011. Assessment of benthic trophic status of marine coastal ecosystems: significance of meiofaunal rare taxa. Estuarine, Coastal and Shelf Science, 93, 420-430.

Pusceddu, A., Dell'Anno, A., Fabiano, M., Danovaro, R., 2009. Quantity and bioavailability of sediment organic matter as signature of benthic trophic state. Marine Ecology Progress Series $375,41-52$

Quetglas, A., Ordines, F., Gonzale, M., Zaragoza, N., Mallol, S., Valls, M., De Mesa, A., 2013. Uncommon pelagic and deep-sea cephalopods in the Mediterranean: new data and literature review. Mediterranean Marine Science, 14, 69-85.

Raicevich, S., Battaglia, P., Fortibuoni, T., Romeo, T., Giovanardi, O., Andaloro, F., 2017. Critical Inconsistencies in Early Implementations of the Marine Strategy Framework Directive and Common Fisheries Policy Objectives Hamper Policy Synergies in Fostering the Sustainable Exploitation of Mediterranean Fisheries Resources. Frontiers in Marine Science, 4 : 316.

Ramirez-Llodra, E., Company, J.B., Sardá, F., Rotllant, G., 2010. Megabenthic diversity patterns and community structure of the Blanes submarine canyon and adjacent slope in the Northwestern Mediterranean: A human overprint? Marine Ecology, 31, 167-182.

Ramirez-Llodra, E., Tyler, P.A., Baker, M.C., Bergstad, O.A., Clark, M.R., Escobar, E., Levin, L.A., Menot, L., Rowden, A.A., Smith, C.R., van Dover, C.L., 2011. Man and the last great wilderness: human impact on the deep sea. PLoS One 6 (8):e22588.

Ramirez-Llodra, E., De Mol, B., Company, J.B., Coll, M., Sardà, F., 2013. Effects of natural and anthropogenic processes in the distribution of marine litter in the deep Mediterranean Sea. Progress in Oceanography, 118, 273-287.

Raoux, C., Bayona, J.M., Miquel, J.C., Teyssie, J.L., Fowler, S.W., Albaiges, J., 1999. Particulate fluxes of aliphatic and aromatic hydrocarbons in near-shore waters to the northwestern Mediterranean Sea, and the effect of continental runoff. Estuarine, Coastal and Shelf Science, 48, 605-616. 
Reid, P.C., Hari, R. E., Beaugrand, G., Livingstone, D.M., Marty, C., Straile, D., Barichivich, J., Goberville, E., Adrian, R., Aono, Y., Brown, R., Foster, J., Groisman, P., Hélaouët, P., Hsu, H., Kirby, R., Knight, J., Kraberg, A., Li, J., Lo, T., Myneni, R.B., North, R.P., Pounds, J. A., Sparks, T., Stübi, R., Tian, Y., Wiltshire, K.H., Xiao, D. and Zhu, Z. (2016), Global impacts of the 1980s regime shift. Global change biology, 22(2), 682-703.

Rixen, M., Beckers, J.M., Levitus, S., Antonov, J., Boyer, T., Maillard, C., Fichaut, M., Balopoulos, E., Iona, S., Dooley, H., Garcia, M.-J., Manca, B., Giorgetti, A., Manzella, G., Mikhailov, N., Pinardi, N., Zavatarelli, M., 2005. The Western Mediterranean Deep Water: A proxy for climate change, Geophysical Research Letters 32, 12, doi: 10.1029/2005gl022702.

Roether, W., Well, R., 2001. Oxygen consumption in the Eastern Mediterranean, Deep Sea Research, Part I , 48, 1535-1551.

Rogers, A.D., 1999. The biology of Lophelia pertusa (Linnaeus 1758) and other deep-water reefforming corals and impacts from human activities. International Review of Hydrobiology, 84 (4), 315-410.

Rombouts, I., Beaugrand, G., Artigas, L.F., Dauvin, J.C., Gevaert, F., Goberville, E., Kopp, D., Lefebvre, S., Luczak, C., Spilmont, N., Travers-Trolet, M., Villanueva, M.C., Kirby, R.R., 2013. Evaluating marine ecosystem health: Case studies of indicators using direct observations and modelling methods. Ecological Indicators 24, 353-365.

Rotllant, G., Abad, E., Sarda, F., Abalos, M., Company, J.B., Rivera, J., 2006. Dioxin compounds in the deep-sea rose shrimp Aristeus antennatus (Risso, 1816) throughout the Mediterranean Sea, Deep- Research, Part I, 53, 1895-1906.

Rountree, R., Aguzzi, J., Marini, S., Fanelli, E., De Leo, F.C., Del Rio, J. and Juanes, F., 2019. Towards an optimal design for ecosystem-level ocean observatories. Advances in Marine Biology, An Annual Review, in press.

Ryan, P. G., Moore, C. J., van Franeker, J. A., Moloney, C. L., 2009. Monitoring the abundance of plastic debris in the marine environment. Philosophical Transactions of the Royal Society B: Biological Sciences, 364, 1999-2012.

Salvadó, J.A., Grimalt, J.O., López, J.F., Palanques, A., Heussner, S., Pasqual, C., Sanchez-Vidal A., Canals, M., 2017. Transfer of lipid molecules and polycyclic aromatic hydrocarbons to open marine waters by dense water cascading events. Progress in Oceanography, 159, 178-194.

Sanchez-Vidal, A., Pasqual, C., Kerherve, P., Calafat, A., Heussner, S., Palanques, A., Durrieu de Madron, X., Canals, M., Puig., P., 2008. Impact of dense shelf water cascading on the transfer 
of organic matter to the deep western Mediterranean basin. Geophysical Research Letters 35, L05605, doi:10.1029/2007GL032825. sea ecosystem by a severe coastal storm; PLoS one, 7, e30395. doi: 10.1371/journal.pone.0030395.

Sanchez-Vidal, A., Thompson, R.C., Canals, M., de Haan, W.P., 2018. The imprint of microfibres in southern European deep seas. PLoS ONE 13 (11): e0207033.

Sardá, F., Calafat, A., Flexas, M., Tselepides, A., Canals, M., Espino, M., Tursi, A., 2004. An introduction to Mediterranean deep-sea biology. Scientia Marina, 68 (suppl. 3), 7-38.

Schembri PJ, Dimech M, Camilleri M, Page, R., 2007. Living deep-water Lophelia and Madrepora corals in Maltese waters (Strait of Sicily, Mediterranean Sea). Cahiers de Biologie Marine, 48, 77-83.

Schroeder, K., Gasparini, G.P., Borghini, M., Ribotti, A., 2009. Experimental evidences of the recent abrupt changes in the deep Western Mediterranean Sea. Dynamics of Mediterranean Deep Waters, $n^{\circ} 38$, Qwara, Malta.

Schroeder, K., Millot, C., Bengara, L., Ben Ismail, S., Bensi, M., Borghini, M., Budillon, G., Cardin, V., Coppola, L., Curtil, C., Drago, A., El Moumni, B., Font, J., Fuda, J.L., Garcla-Lafuente, J., Gasparini, G.P., Kontoyiannis, H., Lefevre, D., Puig, P., Raimbault, P., Rougier, G., Salat, J., Sammari, C., Sanchez Garrido, J. C., Sanchez-Roman, A., Sparnocchia, S., Tamburini, C., Taupier-Letage, I., Theocharis, A., Vargas-Yanez, M., Vetrano, A., 2013. Long-term monitoring programme of the hydrological variability in the Mediterranean Sea: a first overview of the HYDROCHANGES network. Ocean Science 9, 301-324.

Schroeder, K., Chiggiato, J., Bryden, H.L., Borghini, M., Ben Ismail, S., 2016. Abrupt climate shift in the Western Mediterranean Sea, Scientific Reports 6, 23009, doi: 10.1038/srep23009.

Semprucci, F., Sbrocca, C., Rocchi, M., Balsamo, M., 2014. Temporal changes of the meiofaunal assemblage as a tool for the assessment of the ecological quality status. Journal of the Marine Biological Association of the United Kingdom, 95, 247-254.

Shaltout M., Omstedt A., 2014. Recent sea surface temperature trends and future scenarios for the Mediterranean Sea, Oceanologia, 56, 411-443. 
Simoncelli, S., Coatanoan, C., Myroshnychenko, V., Sagen, H., BÄCk, Ö., Scory, S., Grandi, A., Schlitzer, R., Fichaut, M., 2015. Second release of the SeaDataNet aggregated data sets products. SeaDataNet, 10.13155/50382, http://archimer.ifremer.fr/doc/00392/50382/

Simpson, S.D., Meekan, M., Montgomery, J., McCauley, R., Jeffs, A., 2005. Homeward sound, Science 308, 5719, 221-221, doi: 10.1126/science.1107406.

Smith CR, De Leo FC, Bernardino AF, Sweetman AK, Arbizu PM., 2008. Abyssal food limitation, ecosystem structure and climate change. Trends in Ecology \& Evolution, 23, 518-28.

Snelgrove, P.V.R., Soetaert, K., Solan, M., Thrush, S., Wei, C.-L., Danovaro, R, Fulweiler, R.W., Kitazato, H., Ingole, B., Norkko, A., Parkes, R.J., Volkenborn, N., 2018. Contrasting biogeochemical and biological estimates of carbon turnover on the global seafloor. Trends in Ecology \& Evolution, 33, 96-105.

Solé, M., Porte, C., Albaiges, J., 2001. Hydrocarbons, PCBs and DDT in the NW Mediterranean deep-sea fish Mora moro. Deep Sea Research, Part I, 48, 495-513.

Stefanescu, C., Moralesnin, B., Massuti, E., 1994. Fish assemblages on the slope in the Catalan sea (western Mediterranean) - influence of a submarine-canyon. Journal of the Marine Biological Association of the United Kingdom, 74, 499-512.

Stephens, D., Diesing, M., 2014. A comparison of supervised classification methods for the prediction of substrate type using Multibeam acoustic and legacy grain-size data. Plos One 9 , 4, doi: e93950, 10.1371/journal.pone.0093950.

Storelli, M.M., Storelli, A., D'Addabbo, R., Barone, G., Marcotrigiano, G.O., 2004b. Polychlorinated biphenyl residues in deep-sea fish from Mediterranean Sea. Environment International, 30, 343-349.

Storelli, M.M., Perrone, V.G., Marcotrigiano, G.O., 2007. Organochlorine contamination (PCBs and DDTs) in deep-sea fish from the Mediterranean SeaseaSea, Marine Pollution Bulletin, 54, 1968-1971.

Storelli, M.M., Losada, S., Marcotrigiano, G.O., Roosens, L., Barone, G., Neels, H., Covaci, A., 2009. Polychlorinated biphenyl and organochlorine pesticide contamination signatures in deep-sea fish from the Mediterranean Sea, Environmental Research, 109, 851-856.

Stramma, L., Johnson, G.C., Sprintall, J., Mohrholz, V., 2008. Expanding oxygen-minimum zones in the tropical oceans, Science 320, 5876, 655-658. 
Tamburini, C., Canals, M., Durrieu de Madron, X., Houpert, L., Lefèvre, D., Martini, S., and

\section{ANTARES consortium (2013) Deep-Sea Bioluminescence Blooms after Dense Water} Formation at the Ocean Surface. PLoS ONE 8(7): e67523.

Taviani, M., 2002.The Mediterranean benthos from late Miocene up to present: ten million years of dramatic climatic and geological vicissitudes. Biologia Marina Mediterranea, 9, 445-463.

Taviani, M., 2003. Shaping the biogeography of the Mediterranean basin: one geologist's perspective: Marine biogeography of the Mediterranean Sea: Patterns and dynamics of biodiversity. Biogeographia, 24, 15-22. 
Tecchio, S., van Oevelen, D., Soetaert, K., Navarro, J., Ramirez-Llodra, E., 2013. Trophic dynamics of deep-sea megabenthos are mediated by surface productivity, Plos One 8, 5, e63796 10.1371/journal.pone.0063796.

The Petroleum Economist Ltd. (2013). World Energy Atlas. 7th Edition. ISBN 186186343 8. SC (Sang Choy). International Pte Ltd, Singapore.

\section{Thomsen, L., Aguzzi, J., Costa, C., De Leo, F., Ogston, A., Purser, A., 2017. The oceanic biological pump: Rapid carbon transfer to the Deep Sea during winter. Scientific Report, 7, 10763.}

Trudel, M., Rasmussen, J.B., 2001. Predicting mercury concentration in fish using mass balance models. Ecological Applications 11, 517-529.

Tsapakis, M., Apostolaki, M., Eisenreich, S., Stephanou, E.G., 2006. Atmospheric deposition and marine sedimentation fluxes of polycyclic aromatic hydrocarbons in the eastern Mediterranean basin. Environmental Science \& Technology, 40, 4922-4927.

Tubau, X., Canals, M., Lastras, G., Rayo, X., Rivera, J., Amblas, D., 2015. Marine litter on the floor of deep submarine canyons of the Northwestern Mediterranean Sea: The role of hydrodynamic processes. Progress in Oceanography, 134, 379-403.

Ulses, C., Estournel, C., Puig, P., Durrieu de Madron, X., Marsaleix P., 2008. Dense water cascading in the northwestern Mediterranean during the cold winter 2005. Quantification of the export through the Gulf of Lion and the Catalan margin. Geophysical Research Letters, 35, L07610, doi:10.1029/2008GL03325.

UNEP(DEPI)/MED, 2007. Eutrophication Monitoring Strategy for the MED POL (REVISION) UNEP/MAP; WG.321/Inf.5, 9 November 2007.

UNEP, 2012. Implementation of the Ecosystem Approach (EcAp) in the Mediterranean by the contracting parties in the context of the Barcelona Convention for the Protection of the Marine Environment and the Coastal region of the Mediterranean and its Protocols. http://www.rac-spa.org/ecapmed_i

Valls, M., Sweeting, C.J., Olivar, M.P., de Puelles, M.F., Pasqual, C., Polunin, N.V.C., Quetglas, A., 2014. Structure and dynamics of food webs in the water column on shelf and slope grounds of the western Mediterranean. Journal of Marine Systems, 138, 171-181. 
Soltwedel T., Budaeva, N. E., 2011. Carbon flows in the benthic food web at the deep-sea observatory HAUSGARTEN (Fram Strait). Deep Sea Research, Part I, 58, 1069-1083.

Varnavas, S.P., Achilleopoulos, P.P., 1995. Factors controlling the vertical and spatial transport of metal-rich particulate matter in seawater at the outfall of bauxitic red mud toxic waste, Science of the Total Environment, 175, 199-205.

Varnavas, S., Ferentinos, G., Collins, M., 1986. Dispersion of Bauxitic red mud in the Gulf-ofCorinth, Greece, Marine Geology 70, 3-4, 211-222, doi: 10.1016/0025-3227(86)90003-4.

Vasilakopoulos, P., Maravelias, C.D., Tserpes, G., 2014. The alarming decline of Mediterranean fish stocks. Current Biology, 24, 1643-1648.

Vasilis, G., Smith, C. J., Kiparissis, S., Stamouli, C., Dounas, C., Mytilineou, C., 2019. Updating the distribution status of the critically endangered bamboo coral Isidella elongata (Esper, 1788) in the deep Eastern Mediterranean Sea. Regional Studies in Marine Science, 28, 100610, doi.org/10.1016/j.rsma.2019.100610.

Wartzok, D., Ketten, D.R., 1999. Marine mammal sensory systems. In: Reynolds, J., Rommel, S. (eds.) Biology of marine mammals, pp. 117-175, Smithsonian Institution Press, Washington, DC. ISBN: 1560983752

Weilgart, L., 2017. The impact of ocean noise pollution on fish and invertebrates. Report for OceanCare, OCEANCARE \& DALHOUSIE UNIVERSITY, https://www.oceancare.org/wpcontent/uploads/2017/10/noise_and_fish_review_paper-20171016.pdf

Wenz, G.M., 1962. Acoustic Ambient Noise in the Ocean: Spectra and Sources, The Journal of the Acoustical Society of America, 34, 1936-1956.

Woodall, L. C., Sanchez-Vidal, A., Canals, M., Paterson, G. L. J., Coppock, R., Sleight, V., Calafat, A., Rogers, A. D., Narayanaswamy, B. E., Thompson, R. C., 2014. The deep sea is a major sink for microplastic debris. Royal Society Open Science, 1, 140317.

Wurtz, M., Rovere, M., 2015. Atlas of the Mediterranean Seamounts and Seamount-like Structures. IUCN, Gland, Switzerland and Malaga, Spain, pp. 276.

WWF/IUCN, 2004. The Mediterranean deep-sea ecosystems: an overview of their diversity, structure, functioning and anthropogenic impacts, with a proposal for conservation. IUCN, Malaga and WWF, Rome. 
35441866 Xiao, Y.J., Ferreira, J.G., Bricker, S.B., Nunes, J.P., Zhu, M.Y., Zhang, X.L., 2007. Trophic assessment in Chinese coastal systems - Review of methods and application to the Changjiang (Yangtze) Estuary and Jiaozhou Bay, Estuaries and Coasts, 30, 901-918. Orellana, J., Puigdefabregas, J., Canals, M., Espino, M., et al., 2009. Particle fluxes dynamics in Blanes submarine canyon (Northwestern Mediterranean), Progress in Oceanography 82, 4, 239-251. 
36021878 Table 1. List of the descriptors, their definition if GES is achieved and if they are a state or pressure

1879 descriptors. Only D3 is both a state and pressure descriptor as it related to aspects such as the

\begin{tabular}{|c|c|c|c|}
\hline Descriptor & GES & State & Pressure \\
\hline 1 & Biodiversity is maintained & $\mathrm{x}$ & \\
\hline 2 & Non-indigenous species do not adversely alter the ecosystem & & $\mathrm{x}$ \\
\hline 3 & The population of commercial fish species is healthy & $\mathrm{x}$ & $\mathrm{x}$ \\
\hline 4 & Elements of food webs ensure long-term abundance and reproduction & $\mathrm{x}$ & \\
\hline 5 & Eutrophication is minimised & & $\mathrm{x}$ \\
\hline 6 & The sea floor integrity ensures functioning of the ecosystem & $\mathrm{x}$ & \\
\hline 7 & Permanent alteration of hydrographical conditions does not adversely affect the ecosystem & & $\mathrm{x}$ \\
\hline 8 & Concentrations of contaminants give no effects & & $\mathrm{x}$ \\
\hline 9 & Contaminants in seafood are below safe levels & & $\mathrm{x}$ \\
\hline 10 & Marine litter does not cause harm & & $\mathrm{x}$ \\
\hline 11 & Introduction of energy (including underwater noise) does not adversely affect the ecosysten & & $\mathrm{x}$ \\
\hline
\end{tabular}


1884 Figure captions

$3664^{1886}$ Figure 1. Jurisdictional Continental Shelf and deep Mediterranean Sea, with indication of 36651887 jurisdictional continental shelf per each country (including non-EU countries).

36671889 Figure 2. Location of GFCM Geographical Sub-Areas (GSAs) and MSFD Mediterranean national sub36681890 regions. FAO divisions are shown in thumbnail map. 


\section{Jurisdictional Continental Shelf and Deep Mediterranean Sea}

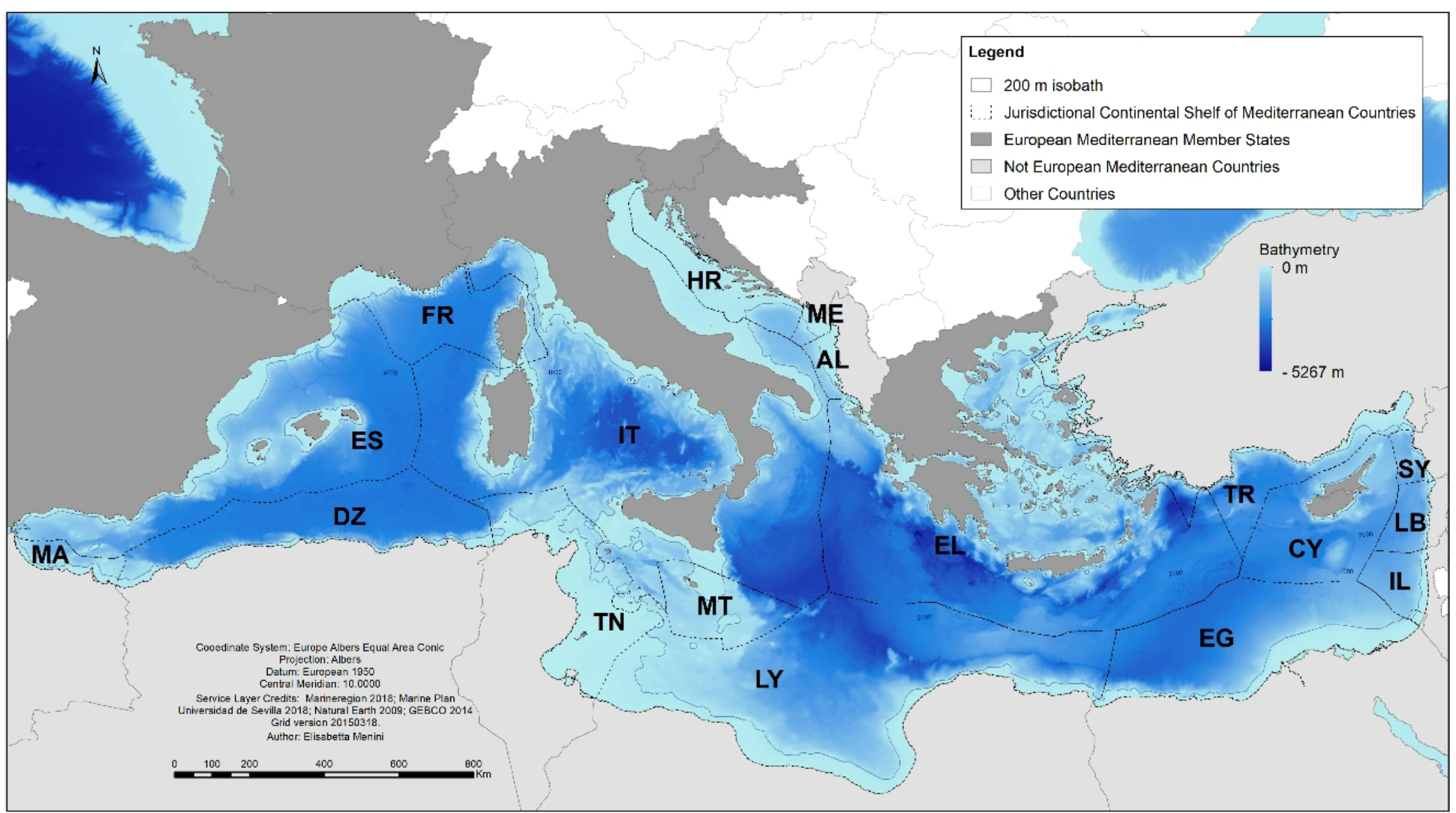

Approximantive percentages of Jurisdicional Contintental Shelf per Country related to the total area of deep sea, calculated with the 200 meters isobath limit, in the Mediterranean Sea: Albania (AL): 0,3\%; Algeria (DZ): $6,1 \%$; Croatia (HR): 0,5\%; Cyprus (CY): 4,8\%; Egypt (EG): 7\%; France (FR): $3,5 \%$; Greece (EL): 20,6\%; Israel (IL): 1,1\%; Italy (IT): 21,2\%; Lebanon (LB): 0,95\%; Lybia (LY): 15,1\%; Malta (MT): 2,3\%; Montenegro (ME): 0,15\%; Morocco (MA): 0,6\%; Spain (ES): $11,1 \%$; Syria (SY): 0,5\%; Tunisia (TN): 1,5\%; Turkey (TR): $2,5 \%$. 


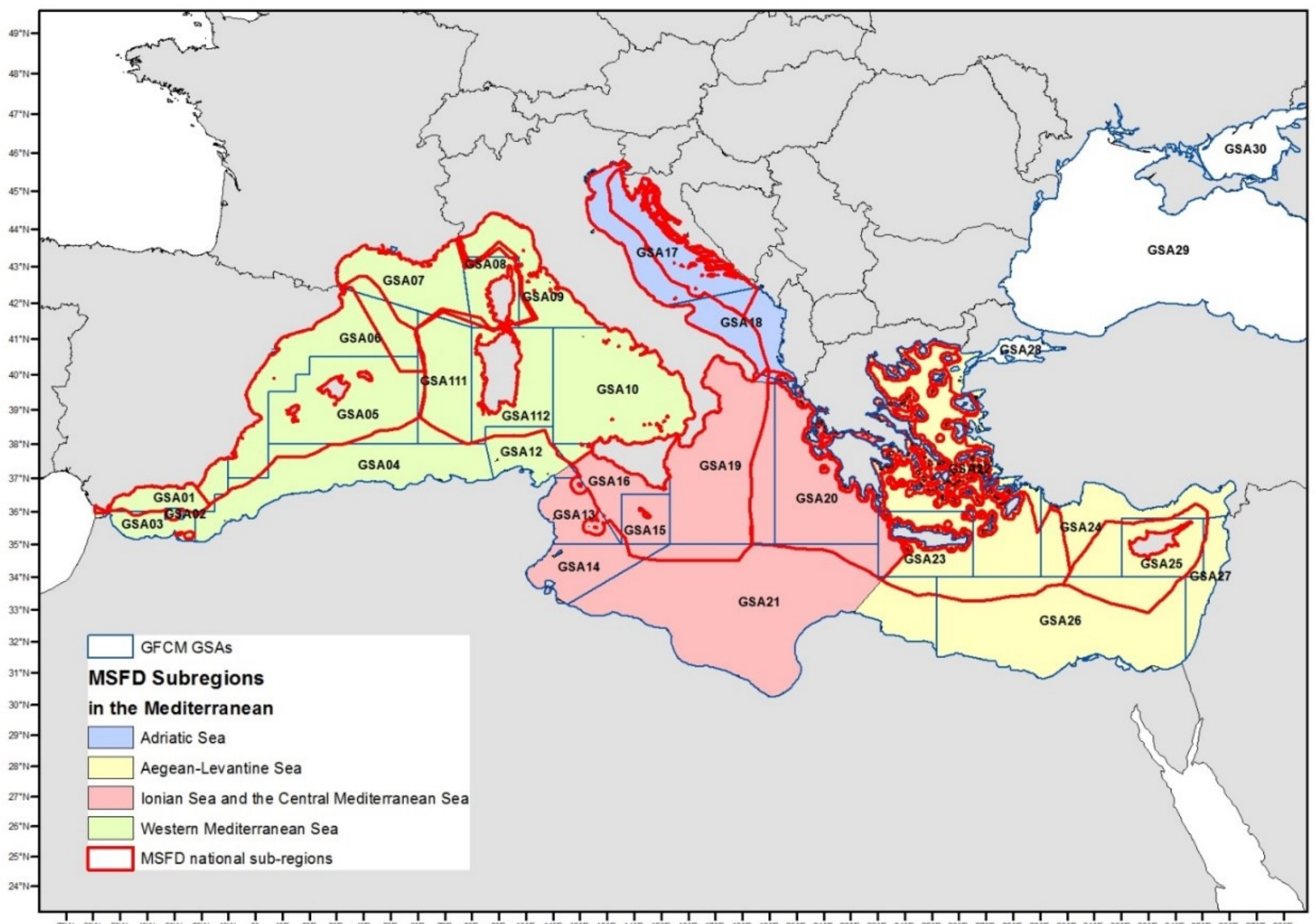

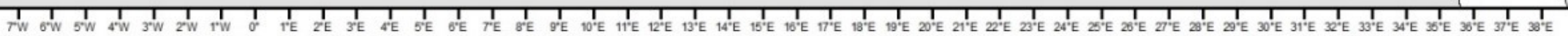

